\title{
Characterization Methods for Small Estuarine Systems in the Mid-Atlantic Region of the United States
}

\author{
John F. Paul ${ }^{1, *}$, John A. Kiddon ${ }^{2}$ and Charles J. Strobel ${ }^{2}$ \\ U.S. Environmental Protection Agency, National Health and Environmental Effects Research Laboratory ${ }^{I}$ Research \\ Triangle Park, NC $27711^{2}$ Narragansett, RI 02882
}

\begin{abstract}
Various statistical methods were applied to spatially discrete data from 14 intensively sampled small estuarine systems in the mid-Atlantic U.S. The number of sites per system ranged from 6 to 37. The surface area of the systems ranged from 1.9 to $193.4 \mathrm{~km}^{2}$. Parameters examined were depth, bottom temperature, bottom salinity, surface chlorophyll $a$, bottom dissolved oxygen, lead concentration in sediments, silt-clay content of sediments, and number of infaunal benthic species. Statistical methods included means, standard deviations, coefficients of variation, empirical cumulative distribution functions, and contours determined by bivariate interpolation and interpolation by kriging. All of these methods were found to be appropriate depending upon the purpose of the characterization. Contouring was applied only to those systems with at least 23 discrete sample sites (7 systems). Cross-validation and randomization techniques were used to compare the two interpolation methods. Kriging was advantageous over bivariate interpolation when moderate to strong spatial correlation existed in the residuals (that is, after removal of the spatial trend with a nonparametric regression model). When kriging was conducted, the removal of the trend was necessary if the stationarity assumption was to be valid. The Delaware/Maryland coastal bays are shallow, well-mixed (horizontally and vertically) systems that exhibit little or no spatial correlation for the parameters examined. The South and Severn Rivers, subsystems of the Chesapeake Bay, exhibited moderate to strong spatial dependence for some parameters. Randomization techniques were used to evaluate the effect of decreasing the number of sites in kriged parameters. Based upon these randomizations, it was found that 23 discrete sites could be used for kriging in estuaries with characteristics similar to those in the mid-Atlantic and if the samples were collected with a comparable design.
\end{abstract}

Keywords: Estuaries, characterization methods, statistical analyses, kriging.

\section{INTRODUCTION}

The estuarine component of the U.S. Environmental Protection Agency's Environmental Monitoring and Assessment Program (EMAP) was designed with probability-based sampling to collect data on indicators of ecological condition. The initial statistical population for estimates of condition was the overall estuarine waters within a biogeographic province and the sampling strata within the province [1,2]. The strata were large systems (estuarine surface area $>260$ $\mathrm{km}^{2}$ with estuarine length/width $<18$ ), large tidal rivers (> $260 \mathrm{~km}^{2}$ with length/width $>18$ ), and small estuarine systems $\left(<260 \mathrm{~km}^{2}\right)$. Over 400 probability sampling sites were visited during the summers of 1990-93 in the Virginian Biogeographic Province (Chesapeake Bay northward to Cape Cod) $[3,4]$. Although not part of the initial design, estimates could nonetheless be made for major estuarine systems that had sufficient sampling sites (typically $>25$ ). Examples for the Virginian Province included Chesapeake Bay, Delaware Bay, and Long Island Sound [5]. However, since only single sites were sampled within each small estuarine system, rea-

\footnotetext{
*Address correspondence to this author at the U.S. Environmental Protection Agency, National Health and Environmental Effects Research Laboratory, Research Triangle Park, NC 27711; Tel: 919-541-3160;

Fax: 919-541-2581; E-mail: paul.john@ep.gov
}

sonable estimates could not be made on condition of an individual small system.

Environmental managers would like to extract as much useful information as possible from available environmental data. And for estuarine systems, in particular, they would like characterization of conditions on at least three scales: regional scale to set the context for interpreting information, the large watershed scale of major systems to determine the issues of importance for priority setting, and small system scale to provide direction to local land management and pollution control. The overall goal is to provide information for environmental managers in their efforts to protect estuarine resources. The data acquired in the EMAP Virginian Province project provide information at the first two scales. In 1993, an EMAP project was conducted in the Delaware/Maryland coastal bays to collect data to characterize these systems [6]. In 1997-98, EMAP conducted a study in the Chesapeake Bay, Delaware Bay, Delmarva coastal bays, and Albemarle-Pamlico estuarine system [7]. One objective was the characterization of small estuarine systems by intensive sampling (spatially) in selected individual systems [8]. The 1993 and 1997-98 studies were intended to address the characterization needs of environmental managers at the third scale. Actual characterization of conditions can be accomplished by various statistical methods, with the method of choice dependent upon the particular question addressed. 
Information on the mean condition for a system assists in setting relative priorities and deciding upon possible management actions across systems. Mean conditions are generally not related to biological significance since there is no relationship to thresholds of effects. Cluster analysis on mean values classifies systems into similar groups. Standard deviations provide estimates of uncertainty about the means and allow one to test for significance of differences in means. Obviously, mean and standard deviations can not be used to characterize the distribution of conditions and spatial variability within an individual system. Coefficients of variation provide an estimate of overall relative variability within a system. Correlations among variables provide information on how the variables are related. Empirical cumulative distribution functions (CDFs) provide information on the distribution of conditions within a system, irrespective of the underlying statistical distribution. If thresholds of effect can be defined, then CDFs can provide percent area of the system in good or poor condition (e.g., [3, 5], However, CDFs do not provide the actual spatial distribution of the conditions (i.e., where in the system the worst conditions are that might be in need of management action).

Contouring of interpolated data presents the spatial distribution of conditions across the system when data from spatially discrete sampling sites are available. Various interpolation methods used in contouring, however, provide different levels of error. The actual error inherent in contoured results is generally unknown. Kriging, an alternative to traditional interpolation methods, is a best linear unbiased estimator for spatially discrete data [9]. It is linear in that weightings are linear combinations of available data, unbiased because it tries to have the mean residual error equal to zero, and best because it minimizes the variance in the errors. Kriging was originally developed for geostatistical applications [10], but has in recent years been applied in many disciplines and to various natural resources [11-14]; [15-17] .

The purpose of this paper is to apply various statistical methods for characterizing spatially discrete data collected from small estuarine systems in the mid-Atlantic region of the U.S. The capabilities of the different statistical analysis techniques are compared for characterizing conditions in the estuarine systems. The characterizations are presented in terms of what information an environmental manager could use in addressing their decisions. The effect of varying number of sample sites within a system on the results is discussed with implications for designing estuarine monitoring programs.

\section{METHODS}

\section{Study Area}

The estuarine area of the U.S. mid-Atlantic region provides the geographic area for this study. This region has been the home to over 21 million people [18]. It also contains a landscape mosaic of ecological systems - lakes, streams, forest, agricultural areas, wetlands, and estuaries. The midAtlantic has all of the environmental problems typically associated with human activities, including air pollution (ozone, acid rain); water quality problems (eutrophication, acid mine drainage); solid waste disposal problems (landfill leachate); large-scale habitat alteration from urbanization, agricultural, and forestry management practices; hydrologic modifications, such as dams and stream channelization; loss of biotic diversity; and threatened and endangered species.

Fourteen individual estuarine systems in the mid-Atlantic that were intensively sampled (spatially) in summers of 1993 and 1997 (Fig. 1) provided data for applying the statistical methods. These systems were chosen from all of those sampled in 1993 and 1997-98 using the criterion that they each had at least 6 discrete sample sites. The sample site selection used a probability-based sampling grid (systematic hexagonal grid) overlain on each system, with random selection of one sample site within each grid. A list of the systems, along with the number of sites sampled and the estuarine surface area in each, appear in Table 1. Based on the number of sites, the systems fall into two groups: those systems with at least 23 sites ("large number of sites"), and those with 6 to 11 sites ("small number of sites"). Some of the analysis procedures were conducted only for the first group. To provide for an analysis of a system with a large number of sites, the combination of Chincoteague Bay, Trappe Creek/Newport Bay, and Sinepuxent Bay was also included as a "combined system" (Table 1).

\section{Data Source}

During the summers of 1993 and 1997, the estuarine systems were sampled for various water, sediment, and biological variables listed in Table 2. The data from 1998 dealt mostly with fish and were not used in this study. Refer to Challou et al. [6] and Strobel et al. [3] for details on sampling and analysis procedures. For illustration purposes in this paper, the following variables were used in applying the characterization methods for the individual systems: depth, surface chlorophyll $a$, bottom temperature, bottom salinity, bottom dissolved oxygen concentration, silt-clay content of sediments, lead concentrations in sediment (smaller number of samples in most systems), and total number of benthic infaunal species. The data used in this study were acquired from the web site www.epa.gov/emap.

\section{Basic Statistical Analysis}

Information on the variables for each system was determined. These were mean, standard deviation, coefficient of variation $(\mathrm{CV})$, minimum, maximum, empirical cumulative distribution function (CDF), and linearly interpolated contours. Agglomerative hierarchical clustering was conducted on mean values to identify systems in similar groups [19]. Euclidian distance was used with a complete linkage model. The cluster analyses were conducted separately for the systems with large and small number of sites. Spearman rank correlations $(\rho)$ between variables within each system were calculated; variables were typically non-normally distributed. Tests for difference in means for each variable between systems were conducted using t-tests. Correlation matrices of seven variables in each system (lead excluded) were tested for differences using procedure in Morrison [20]. The estimation formula as presented in Hyland et al. [21] was used to construct the CDFs. The CDFs were tested for difference between systems using the Kolmogorov-Smirnov test [22]. There were no non-detects in the data sets used. A few data values were missing; these missing values were assumed to be random (i.e., the results for non-missing data were assumed to include the missing values). The significance level for all tests (p-value) was 0.05 . 


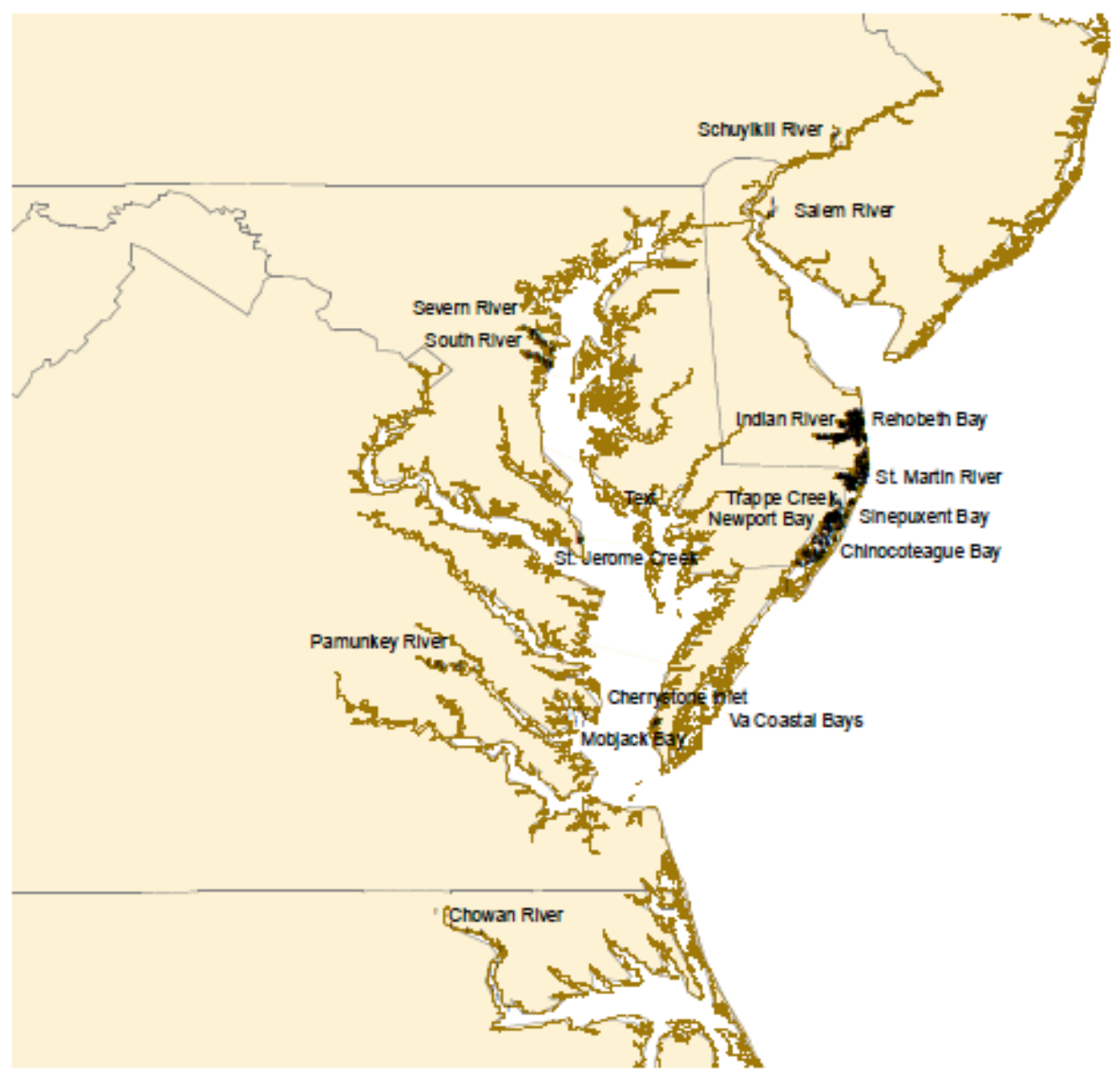

Fig. (1). Map of study area, small estuarine systems sampled, and sampling sites within small systems.

Table 1. Mid-Atlantic Estuarine Systems Used in Characterization Analysis

\begin{tabular}{|c|c|c|c|}
\hline & Number of sample sites & Year sampled & Estuarine surface area $\left(\mathrm{km}^{2}\right)$ \\
\hline St. Martin River & 25 & 1993 & 11.3 \\
\hline Trappe Creek/Newport Bay & 23 & 1993 & 19.9 \\
\hline South River & 27 & 1997 & 23.4 \\
\hline Severn River & 29 & 1997 & 24.7 \\
\hline Cherrystone Inlet & 9 & 1997 & 5.4 \\
\hline Chowan River & 10 & 1997 & 12.9 \\
\hline Salem River & 10 & 1997 & 1.9 \\
\hline Schuykill River & 6 & 1997 & 2.4 \\
\hline St. Jerome Creek & 10 & 1997 & 4.5 \\
\hline Combined system $^{\dagger}$ & 63 & 1993 & 235.5 \\
\hline
\end{tabular}

${ }^{\dagger}$ combination of Chincoteague Bay, Trappe Creek/Newport Bay, and Sinepuxent Bay 
Table 2. Water Column and Sediment Compartment Variables Measured in Mid-Atlantic Estuarine Systems at Sampling Sites in 1993 and $1997[6 ; 8]$

\begin{tabular}{|l|l|}
\hline \multicolumn{1}{|c|}{ Water Column Variables } & \multicolumn{1}{c|}{ Sediment Compartment Variables } \\
\hline \hline depth & grain size (\% silt/clay) \\
salinity & $\begin{array}{l}\text { sediment toxicity (amphipod and Microtox®) } \\
\text { invertebrate macrofauna } \\
\text { organic contaminants (24 PAHs, 18 PCB congeners, DDTs, 11 pesticides, butyltins) } \\
\text { dissolved oxygen } \\
\mathrm{pH} \\
\begin{array}{l}\text { dissolved and particulate nutrients } \\
\text { chlorophyll } a\end{array}\end{array}$ \\
\hline total suspended solids & \\
\hline secchi depth & \\
\hline
\end{tabular}

Contouring takes variables that may be on irregular grids, and estimates them on a regular and significantly finer grid. For this analysis, the value at a point that was contoured was estimated by a weighted linear combination of the nearest sample points (bivariate interpolation [23]). Contours were not produced for the systems with small number of sites. Geographic coordinates were converted to UTM coordinates for linear interpolation and contouring. The contouring software was capable of constraining the contours so that land areas were excluded from the contoured domain. SAS [24] and S-Plus software [25] were used for statistical analysis and contouring.

\section{Kriging Analysis}

Since kriging is not as well understood as the other methods, we provide a simple introduction to the topic. Kriging assumes that two observations taken near each other are typically more alike than observations at a much greater distance apart. Modeling this spatial correlation is usually accomplished through construction of an empirical variogram (e.g., Goovaerts [15]. The variogram is a measure of the dissimilarity between two observations that are a distance $|\boldsymbol{h}|$ apart. (Bold letters are used here to denote vectors.) The empirical variogram is defined as

$$
\gamma(\boldsymbol{h})=\frac{1}{2 N(\boldsymbol{h})} \sum_{n=1}^{N(\boldsymbol{h})}\left|v_{i}(\boldsymbol{x}+\boldsymbol{h})-v(\boldsymbol{h})\right|^{2},
$$

where $\gamma(\boldsymbol{h})$ is the empirical variogram and $N(\boldsymbol{h})$ is number of pairs of sample points for variable values $v_{i}(\boldsymbol{x})$ at the separation distance $\boldsymbol{h}$. By definition, the variogram is one-half the average squared difference between the paired data values. Equation (1) is often referred to as the semivariogram because of the one-half factor. For some variograms, the average squared difference between the pairs of point values no longer increases as the separation distance increases, i.e., the variogram flattens out. The distance at which this occurs is called the range, while the variogram value at that distance is referred to as the sill. In practice, there is a discontinuity in the variogram at the origin, i.e., it does not go to zero. This is called the nugget effect and is attributed to measurement error and variation within the minimum sampling site spacing.

The variogram in equation (1) is the classical formulation given by Matheron [10]. Cressie and Hawkins [26] developed a robust estimator that reduces the effect of outliers without removing data points from a data set. This robust estimator is based on the fourth power of the square root of the absolute difference:

$\gamma(\boldsymbol{h})=\frac{\left|\frac{1}{2|\mathrm{~N}(\mathrm{~h})|} \sum_{\mathrm{n}=1}^{\mathrm{N}(h)}\right| v_{i}(\boldsymbol{x}+\boldsymbol{h})-\left.\left.v_{i}(\boldsymbol{x})\right|^{1 / 2}\right|^{4}}{0.457+0.494 /|\mathrm{N}(\boldsymbol{h})|}$.

This form of the empirical variogram was used in the analysis.

Two assumptions underlying the procedures developed for kriging are isotropy and stationarity of variograms [9], referred to as the intrinsic hypothesis by Matheron. Isotropy refers to the independence of the variogram with respect to direction. A complicating factor in spatial relationships is a change in correlation as a function of direction. Anisotropy refers to variograms that are functions of distance and direction. Directional variograms were used to evaluate the degree of anisotropy. Stationarity means that the variogram is a function only of the separation distance of points, not on actual location. A stationary variogram is independent of spatial location, that is, no spatial trend exists in the data.

The occurrence of spatial trends in the data can be accounted for in two ways. For the first, when the range exists and the trend is minimal over distances up to the range, then there is no practical need to detrend the data. Strictly speaking, the stationarity assumption applies not to the entire data set but only to the search neighborhood [9]. The actual search neighborhood can be less than the total sampled area when a large number of sites is available for computing lags (differences in distances). In the second way, regression models, such as parametric or non-parametric local regression (loess) models [27], are fit to the data to remove the trend. The variogram construction and kriging are then conducted on the residuals from removal of the trend. For this study, loess models were fit for each variable to remove spatial trends. Refer to Kaluzny et al. (1998) for details and implementation of loess model.

Since empirical variogram values are derived only at specific lags, a continuous function, or model, is fit so that values of $v(h)$ can be obtained at all distances $(h)$. Typical models include linear, exponential, spherical, and Gaussian, although the Gaussian model is known to lead to unstable krig- 
ing systems and artifacts in the estimated maps (Goovaerts [28] referencing Wackernagel [29], pp. 109-111). Once the model is fit, the nugget, sill, and range of the variogram can be obtained. For example, the spherical model is

$$
\begin{aligned}
\gamma(h)= & C_{0}+C_{1}\left(1.5 \frac{h}{r}-0.5\left(\frac{h}{r}\right)^{3}\right), & & \mathrm{h} \leq \mathrm{r} \\
& =C_{0}+C_{1}, & & \mathrm{~h}>\mathrm{r}
\end{aligned}
$$

the exponential model is

$\gamma(h)=C_{0}+C_{1}\left(1-\exp \left(-\frac{h}{r}\right)\right)$

and the linear model is

$\gamma(h)=C_{0}+C_{1} h$,

where $C_{0}$ is nugget variance, $r$ is the range parameter, and the sill or total variance is $\left(C_{0}+C_{l}\right)$. The spherical and exponential models are bounded in that they reach a sill either at a given range value (spherical model) or asymptotically (exponential model). The practical range is defined as the distance at which the model value is $95 \%$ of the sill, that is, $3 r$ for the exponential model. The linear model is unbounded.

Spherical, exponential, and linear functions were evaluated as possible models for the empirical variograms for the variables for each system. Once the form of the variogram is known, estimation of the variables at unsampled locations $\left(v^{*}(u)\right)$ is conducted by ordinary kriging, which uses only the available data for the variable to be estimated. That is, ordinary kriging estimates values as a linear combination of neighboring observations $\left(v\left(u_{\alpha}\right), \alpha=1, \ldots \mathrm{n}\right)$ :

$v *(x)=\sum_{\alpha=1}^{n(x)} \lambda_{\alpha}(x) v\left(x_{\alpha}\right)$.

The ordinary kriging weights, $\lambda_{\alpha}(x)$, are chosen to minimize the error variance under the constraint that the estimation be unbiased. Ordinary kriging also provides a standard error estimate. This can be combined under certain assumptions with the estimated value to derive confidence intervals for the uncertainty in the resulting values.

The assumed spatial model for each variable consists of three components: a spatial component for the trend (the loess model), a random but spatially correlated component (based on the modeled variogram), and a random noise representing the residual error (assumed to be normal). The kriged estimate for the residuals is added to the loess component to predict values for the variables. Variogram construction and kriging were only applied to the systems with at least 23 sample sites. A small number of sample points limits the number of lags that can be used for construction of the empirical variogram and the resultant fit of the continuous function [30].

The procedure used to select the functional form for the model variogram was as follows: a spherical function was fit to the empirical variogram. If the range was much greater than the system size, then a linear model was selected and appropriate coefficients chosen. If the range was zero (nugget equaled total variance), then the model is "pure nugget," with no spatial dependence in the variogram. If the spherical model was determined to be neither linear nor pure nugget, then a cross-validation was conducted to compare with the exponential model fit. Cross-validation is a technique to determine the reliability of the estimation procedure in reproducing the sample value. This is accomplished by removing each sample value from the sample and reestimating the removed value from the remaining values [9]. The mean square error was calculated for the kriged predictions as an estimate of the variability, where $v\left(x_{i}\right)$ and $v^{*}\left(x_{i}\right)$ represent the actual and estimated values, respectively:

$$
\operatorname{MSE}=\frac{1}{n} \sum_{i=1}^{n}\left|v\left(x_{i}\right)-v *\left(x_{i}\right)\right|^{2} \text {. }
$$

The model with the smaller MSE was selected. The $\mathrm{S}+$ SpatialStats module in S-Plus [31] was used for construction of the empirical variograms and implementation of the kriging procedures. The geographic coordinates were transformed to UTM coordinates for kriging.

\section{Effect of Sample Size on Kriging}

To estimate the effect of sample size, simulations were conducted for those systems with $\mathrm{N}>35$ (Indian River, Chincoteague Bay, and the combination of Chincoteague Bay, Trappe Creek/Newport Bay, and Sinepuxent Bay) with all of the variables. The sample size, $\mathrm{N}_{S}$, was decreased in steps of 5 (10 for combined system) in each of these systems from the maximum until $\mathrm{N}_{\mathrm{S}}$ was less than 25 . Randomization techniques [32] were used to evaluate for each value of $\mathrm{N}_{S}$. A random selection of $\mathrm{N}_{\mathrm{S}}\left(<\mathrm{N}_{\max }\right)$ sites out of the possible $\mathrm{N}_{\max }$ was made, and the entire kriging process was conducted for the $\mathrm{N}_{\mathrm{S}}$ randomly-selected samples. For each value of $\mathrm{N}_{\mathrm{S}}$, 100 randomizations were conducted.

The relative mean square error of prediction (RMSE) was used as a criterion to compare the accuracy of the kriged estimates from the simulations:

RMSE = MSE / total variance of sample

The Spearman rank correlation coefficients were calculated between values estimated for reduced sample sizes $\left(\mathrm{N}_{\mathrm{S}}\right.$ samples) and values from the maximum sample size [16, 33]. The median results from the randomizations were compared.

\section{Evaluation of Interpolation Methods}

The performance of the kriged estimate was compared to that of the bivariate interpolation. This was conducted using cross-validation for Severn River, Indian River, and combined system. The comparison criterion was the ratio of mean square errors (MSE). Since we found that contours by kriging and by bivariate interpolation were not much different for most variables, we present results for kriging focusing on the possible increase in uncertainty rather than presenting contour plots.

\section{RESULTS}

\section{Basic Statistical Results}

The number of samples, mean, standard deviation, coefficient of variation, minimum, and maximum for the variables for each system are listed in Table 3. CVs can express the variability between systems. Low CVs were exhibited for bottom temperature and salinity, while higher values were shown for chlorophyll $a$, sediment silt-clay content, and 
Table 3. Basic Statistical Results for Conditions in Intensively Sampled Estuarine Systems

\begin{tabular}{|c|c|c|c|c|c|c|c|c|c|c|c|c|}
\hline & Mean & $\sigma \div$ & $\mathbf{C V}$ & Med & Min & $\operatorname{Max}$ & Mean & $\sigma \doteqdot$ & $\mathbf{C V}^{*}$ & Med & Min & Max \\
\hline & \multicolumn{6}{|c|}{ Rehobeth Bay $(\mathrm{N}=30, \mathrm{~N}=6$ for $\mathrm{Pb})$} & \multicolumn{6}{|c|}{ Indian River $(\mathrm{N}=37, \mathrm{~N}=4$ for $\mathrm{Pb})$} \\
\hline Depth (m) & 1.3 & 0.6 & 45.5 & 1.2 & 0.6 & 3.4 & 1.5 & 0.6 & 37.7 & 1.5 & 0.6 & 3.7 \\
\hline Bottom temperature $\left({ }^{\circ} \mathrm{C}\right)$ & 25.7 & 2.7 & 10.7 & 25.7 & 19.4 & 29.8 & 26.5 & 3.8 & 14.5 & 26.6 & 19.2 & 37.4 \\
\hline Bottom Salinity (o/oo) & 29.7 & 2.6 & 8.6 & 30.4 & 21.6 & 32.9 & 26.4 & 4.9 & 18.7 & 26.9 & 8.4 & 32.1 \\
\hline Surface chlorophyll $a(: g / L)$ & 13.3 & 9.5 & 71.4 & 10.3 & 1.7 & 43.1 & 28.1 & 21.5 & 76.5 & 21.1 & 2.9 & 95.6 \\
\hline Bottom oxygen (mg/L) & 6.7 & 1.3 & 19.6 & 6.3 & 4.6 & 10.5 & 6.0 & 1.5 & 24.5 & 5.7 & 3.8 & 9.6 \\
\hline Sediment silt-clay (\%) & 37.0 & 36.7 & 99.1 & 12.5 & 2.2 & 98.3 & 65.4 & 30.0 & 45.9 & 77.3 & 2.0 & 99.8 \\
\hline Sediment Pb (:g/g) & 38.9 & 9.9 & 25.6 & 42.7 & 19.0 & 45.0 & 58.6 & 0.6 & 1.0 & 58.6 & 57.8 & 59.2 \\
\hline \multirow[t]{2}{*}{ Benthic infaunal species $(\#)^{\dagger}$} & 20.8 & 6.9 & 33.3 & 21.5 & 3.0 & 31.0 & 20.2 & 7.1 & 35.3 & 21.0 & 1.0 & 32.0 \\
\hline & \multicolumn{6}{|c|}{ St. Martin River $(\mathrm{N}=25, \mathrm{~N}=4$ for $\mathrm{Pb})$} & \multicolumn{6}{|c|}{ Trappe Creek/Newport Bay $(\mathrm{N}=23, \mathrm{~N}=1$ for $\mathrm{Pb})$} \\
\hline Depth (m) & 1.3 & 0.3 & 22.9 & 1.2 & 0.6 & 1.8 & 1.6 & 0.3 & 20.1 & 1.8 & 0.9 & 2.1 \\
\hline Bottom temperature $\left({ }^{\circ} \mathrm{C}\right)$ & 27.4 & 1.8 & 6.6 & 27.2 & 24.1 & 31.7 & 25.6 & 1.9 & 7.6 & 25.6 & 21.4 & 28.2 \\
\hline Bottom Salinity (o/oo) & 28.6 & 2.6 & 9.1 & 29.4 & 23.7 & 31.6 & 27.7 & 2.1 & 7.4 & 27.6 & 23.1 & 30.9 \\
\hline Surface chlorophyll $a(: g / L)$ & 19.9 & 6.2 & 31.0 & 18.0 & 13.2 & 32.1 & 17.7 & 15.2 & 85.6 & 12.2 & 2.4 & 60.3 \\
\hline Bottom oxygen (mg/L) & 5.7 & 1.1 & 19.6 & 5.8 & 3.0 & 8.3 & 6.2 & 0.8 & 13.5 & 6.2 & 4.3 & 8.3 \\
\hline Sediment silt-clay (\%) & 57.7 & 27.3 & 47.4 & 69.2 & 4.7 & 91.4 & 66.1 & 28.4 & 42.9 & 76.8 & 2.5 & 95.7 \\
\hline Sediment $\mathrm{Pb}(: \mathrm{g} / \mathrm{g})$ & 22.0 & 10.3 & 47.0 & 18.7 & 14.0 & 36.6 & 65.2 & - & - & 65.2 & 65.2 & 65.2 \\
\hline \multirow[t]{2}{*}{ Benthic infaunal species $(\#)^{\dagger}$} & 20.8 & 9.7 & 46.4 & 20.0 & 1.0 & 38.0 & 26.4 & 6.9 & 26.1 & 28.0 & 11.0 & 38.0 \\
\hline & \multicolumn{6}{|c|}{ Chincoteague Bay $(\mathrm{N}=36, \mathrm{~N}=6$ for $\mathrm{Pb})$} & \multicolumn{6}{|c|}{ South River $(\mathrm{N}=27)$} \\
\hline Depth (m) & 1.5 & 0.5 & 29.8 & 1.6 & 0.6 & 2.1 & 3.1 & 1.5 & 49.5 & 4.8 & 0.8 & 6.2 \\
\hline Bottom temperature $\left({ }^{\circ} \mathrm{C}\right)$ & 24.9 & 2.3 & 9.4 & 25.8 & 21.0 & 28.8 & 25.9 & 1.7 & 6.5 & 11.0 & 24.3 & 31.6 \\
\hline Bottom Salinity (o/oo) & 32.2 & 2.4 & 7.4 & 33.0 & 26.9 & 35.0 & 11.7 & 1.0 & 8.9 & 24.9 & 9.4 & 13.4 \\
\hline Surface chlorophyll $a(: \mathrm{g} / \mathrm{L})$ & 5.7 & 4.8 & 84.1 & 4.3 & 0.1 & 19.7 & 24.9 & 14.3 & 57.6 & 34.9 & 5.6 & 54.3 \\
\hline Bottom oxygen (mg/L) & 6.3 & 0.9 & 14.7 & 6.3 & 4.2 & 8.8 & 5.1 & 2.8 & 54.8 & 12.0 & 0.1 & 11.7 \\
\hline Sediment silt-clay (\%) & 34.7 & 31.7 & 91.4 & 24.6 & 1.4 & 99.9 & 59.0 & 41.4 & 70.1 & 3.2 & 0.0 & 99.3 \\
\hline Sediment Pb (:g/g) & 37.8 & 17.6 & 46.7 & 40.0 & 14.9 & 66.2 & 33.9 & 21.7 & 64.1 & 83.8 & 4.2 & 68.7 \\
\hline \multirow[t]{2}{*}{ Benthic infaunal species $(\#)^{\dagger}$} & 30.5 & 8.2 & 26.9 & 30.5 & 16.0 & 57.0 & 10.3 & 4.8 & 46.5 & 21.6 & 0.0 & 21.0 \\
\hline & \multicolumn{6}{|c|}{ Severn River $(\mathrm{N}=29)$} & \multicolumn{6}{|c|}{ Combined system $^{\&}(\mathrm{~N}=63, \mathrm{~N}=7$ for $\mathrm{Pb})$} \\
\hline Depth (m) & 4.7 & 2.7 & 58.6 & 3.0 & 0.8 & 9.2 & 1.6 & 0.4 & 26.6 & 1.6 & 0.6 & 2.1 \\
\hline Bottom temperature $\left({ }^{\circ} \mathrm{C}\right)$ & 25.3 & 1.2 & 4.9 & 8.0 & 24.1 & 27.7 & 25.1 & 2.1 & 8.5 & 25.6 & 21.0 & 28.8 \\
\hline Bottom Salinity (o/oo) & 10.7 & 1.5 & 14.0 & 24.8 & 7.0 & 12.8 & 30.4 & 3.1 & 10.1 & 29.8 & 23.1 & 35.0 \\
\hline Surface chlorophyll $a(: \mathrm{g} / \mathrm{L})$ & 16.7 & 7.7 & 45.8 & 46.3 & 5.9 & 32.4 & 10.2 & 11.3 & 110.9 & 6.5 & 0.1 & 60.3 \\
\hline Bottom oxygen (mg/L) & 3.5 & 3.0 & 86.2 & 10.8 & 0.1 & 9.5 & 6.2 & 0.9 & 13.8 & 6.2 & 4.2 & 8.8 \\
\hline Sediment silt-clay (\%) & 62.0 & 41.6 & 67.1 & 5.5 & 0.5 & 99.1 & 45.6 & 33.5 & 73.4 & 40.5 & 1.4 & 99.9 \\
\hline Sediment Pb (:g/g) & 48.1 & 32.5 & 67.6 & 88.6 & 4.3 & 115.0 & 41.7 & 19.2 & 45.9 & 40.2 & 14.9 & 66.2 \\
\hline Benthic infaunal species $(\#)^{\dagger}$ & 8.4 & 7.4 & 87.8 & 13.2 & 0.0 & 24.0 & 29.2 & 7.8 & 26.6 & 29.0 & 11.0 & 57.0 \\
\hline
\end{tabular}


Table 3. contd....

\begin{tabular}{|c|c|c|c|c|c|c|c|c|c|c|c|c|}
\hline & Mean & $\sigma \ddagger$ & $\mathbf{C V}^{*}$ & Med & Min & Max & Mean & $\sigma \ddagger$ & $\mathbf{C V}^{*}$ & Med & Min & $\operatorname{Max}$ \\
\hline & \multicolumn{6}{|c|}{ Cherrystone Inlet $(\mathrm{N}=9)$} & \multicolumn{6}{|c|}{ Chowan River $(\mathrm{N}=10)$} \\
\hline Bottom temperature $\left({ }^{\circ} \mathrm{C}\right)$ & 26.0 & 0.5 & 2.0 & 26.0 & 25.1 & 26.7 & 27.4 & 0.3 & 1.0 & 27.3 & 27.0 & 27.8 \\
\hline Bottom Salinity (o/oo) & 23.0 & 0.9 & 3.7 & 23.2 & 21.8 & 24.0 & 0.1 & 0.2 & 169.3 & 0.1 & 0.0 & 0.5 \\
\hline Bottom oxygen (mg/L) & 7.6 & 0.7 & 9.4 & 7.2 & 6.7 & 8.8 & 5.7 & 1.5 & 26.0 & 6.2 & 3.5 & 7.4 \\
\hline Sediment silt-clay (\%) & 76.4 & 32.0 & 41.9 & 89.2 & 1.5 & 97.3 & 66.8 & 41.7 & 62.5 & 89.9 & 1.4 & 96.8 \\
\hline Sediment $\mathrm{Pb}(: \mathrm{g} / \mathrm{g})$ & 19.3 & 6.8 & 35.1 & 20.8 & 3.4 & 25.2 & 28.7 & 12.8 & 44.6 & 35.2 & 8.2 & 39.5 \\
\hline Benthic infaunal species $(\#)^{\dagger}$ & 14.4 & 9.3 & 64.6 & 11.0 & 5.0 & 35.0 & 14.0 & 4.2 & 30.1 & 13.0 & 9.0 & 20.0 \\
\hline Bottom temperature $\left({ }^{\circ} \mathrm{C}\right)$ & 25.5 & 0.5 & 1.9 & 25.4 & 24.6 & 26.0 & 28.4 & 0.8 & 2.9 & 28.2 & 27.5 & 30.1 \\
\hline Bottom Salinity (o/oo) & 20.3 & 0.8 & 4.0 & 20.2 & 18.9 & 21.5 & 1.3 & 3.1 & 227.3 & 0.2 & 0.1 & 10.5 \\
\hline Surface chlorophyll $a(: \mathrm{g} / \mathrm{L})$ & 11.5 & 2.2 & 18.8 & 11.0 & 8.9 & 14.9 & 17.2 & 7.2 & 41.5 & 13.6 & 10.2 & 32.2 \\
\hline Bottom oxygen (mg/L) & 6.4 & 1.2 & 18.0 & 6.4 & 4.9 & 8.4 & 5.9 & 0.5 & 8.6 & 5.9 & 5.0 & 6.9 \\
\hline Sediment silt-clay (\%) & 44.7 & 46.5 & 104.1 & 14.0 & 1.9 & 99.5 & 54.4 & 43.3 & 79.6 & 68.8 & 1.4 & 98.3 \\
\hline Sediment $\mathrm{Pb}(: \mathrm{g} / \mathrm{g})$ & 12.2 & 9.4 & 77.5 & 6.4 & 2.9 & 24.0 & 18.6 & 10.0 & 53.6 & 18.2 & 4.7 & 37.5 \\
\hline Benthic infaunal species $(\#)^{\dagger}$ & 17.7 & 7.9 & 44.7 & 20.0 & 7.0 & 27.0 & 15.7 & 5.3 & 34.0 & 12.0 & 10.0 & 24.0 \\
\hline Bottom oxygen (mg/L) & 5.4 & 2.2 & 39.7 & 6.1 & 0.0 & 7.7 & 6.0 & 1.7 & 28.6 & 6.4 & 3.6 & 8.2 \\
\hline Sediment silt-clay (\%) & 73.2 & 37.3 & 50.9 & 91.0 & 4.4 & 99.2 & 59.0 & 35.6 & 60.3 & 40.7 & 21.8 & 98.5 \\
\hline Sediment $\mathrm{Pb}(: \mathrm{g} / \mathrm{g})$ & 47.4 & 21.4 & 45.1 & 55.4 & 18.2 & 84.0 & 117.1 & 20.4 & 17.4 & 111.0 & 94.6 & 147.0 \\
\hline \multirow[t]{2}{*}{ Benthic infaunal species $(\#)^{\dagger}$} & 10.5 & 1.4 & 13.7 & 10.0 & 9.0 & 13.0 & 14.3 & 1.4 & 9.5 & 14.0 & 13.0 & 16.0 \\
\hline & \multicolumn{12}{|c|}{ St. Jerome Creek $(\mathrm{N}=10)$} \\
\hline Depth (m) & 1.5 & 0.4 & 26.7 & 1.5 & 1.0 & 2.2 & & & & & & \\
\hline Bottom temperature $\left({ }^{\circ} \mathrm{C}\right)$ & 26.5 & 0.6 & 2.4 & 26.6 & 25.5 & 27.4 & & & & & & \\
\hline Bottom Salinity (o/oo) & 15.4 & 0.3 & 2.2 & 15.4 & 14.7 & 15.8 & & & & & & \\
\hline Surface chlorophyll $a(: \mathrm{g} / \mathrm{L})$ & 17.0 & 10.7 & 62.6 & 15.0 & 7.7 & 40.1 & & & & & & \\
\hline Bottom oxygen (mg/L) & 7.2 & 1.1 & 15.1 & 7.4 & 4.7 & 8.5 & & & & & & \\
\hline Sediment silt-clay (\%) & 59.7 & 44.5 & 74.5 & 89.8 & 1.9 & 98.6 & & & & & & \\
\hline Sediment $\mathrm{Pb}(: \mathrm{g} / \mathrm{g})$ & 16.4 & 9.2 & 56.3 & 18.0 & 5.1 & 27.8 & & & & & & \\
\hline Benthic infaunal species $(\#)^{\dagger}$ & 13.9 & 4.3 & 30.6 & 16.0 & 7.0 & 19.0 & & & & & & \\
\hline
\end{tabular}

${ }^{\dagger}$ Based on 1 grab sample per station except South and Severn Rivers that are based on 3 grabs per station

$\ddagger \sigma$ - standard deviation

${ }^{*} \mathrm{CV}$ - coefficient of variation

\& combination of Chincoteague Bay, Trappe Creek/Newport Bay, and Sinepuxent Bay 
number of benthic species. The high CVs for bottom salinity in Chowan and Pamunkey Rivers (> 100\%) were due to the small mean values. Every system had silt-clay content of sediment spanning the range of $0-100 \%$. For the group of systems with a large number of sites, the two systems from the Chesapeake Bay (South and Severn Rivers) were different from the others (Fig. 2): they were deeper and fresher at the bottom and had lower bottom dissolved oxygen and numbers of benthic species. Chowan, Pamunkey, Salem, and Schuykill Rivers were tidal fresh systems. Chincoteague Bay had the sandiest sediments. Cherrystone Inlet and Salem River had sediments with the highest median silt-clay content. South and Severn Rivers had similar variable distributions with the exception that Severn River had higher sediment $\mathrm{Pb}$ concentrations. Schuykill River had the highest sediment lead concentrations. St. Martins, Indian River, and Rehobeth Bay were similar with the exception that Indian River had higher chlorophyll $a$ concentrations and Rehobeth Bay was sandier. Within the coastal bays, Chincoteague Bay had more benthic species, low chlorophyll $a$, and was sandier and saltier.

The cluster analyses resulted in the following groupings for the systems (Fig. 3):

$$
\operatorname{Depth}(\mathrm{m})
$$

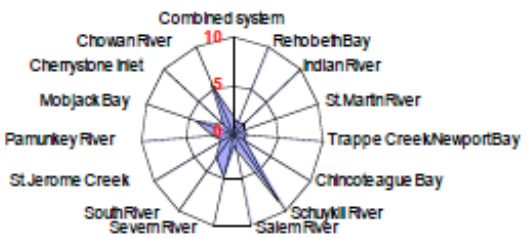

Bottom temperature $(\circ C)$
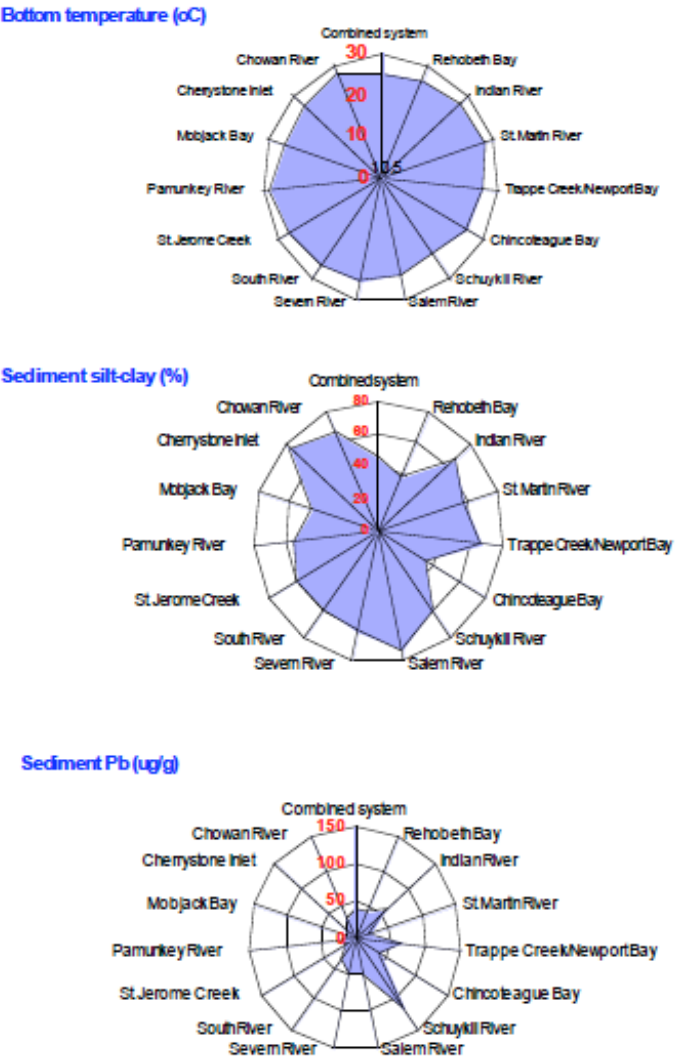

Fig. (2). Radar plot of means for all variables and all systems.
- Severn and South Rivers,

- Rehobeth Bay, St. Martins River, Trappe Creek Creek/Newport Bay, Indian River, and Chincoteague Bay,

- Cherrystone Inlet, Mobjack Bay, St. Jerome Creek, Chowan, Pamunkey, and Salem Rivers,

- Schuykill River.

The results of the t-test for difference in mean values at the $p=0.05$ significance level are shown in Table 4 . The means for all of the seven variables from Indian River and St. Martin River were not statistically significantly different. Except for salinity, the means for Trappe Creek/Newport Bay and combined system, and Chincoteague Bay and combined system were not statistically significantly different, as might be expected. The means for Indian River and Trappe Creek/Newport Bay were not statistically significantly different except for number of benthic species.

The results of the test for difference in distributions at the $p=0.05$ significance level are shown in Table 5. None of the CDFs for Indian and St. Martins Rivers were statistically significantly different. The following systems had CDFs not

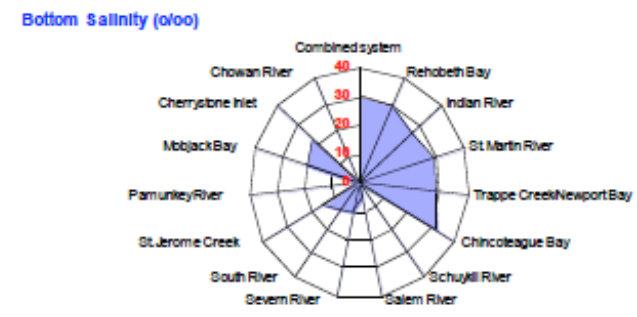

Bottom oxygen ( $\mathrm{mg} / \mathrm{L})$
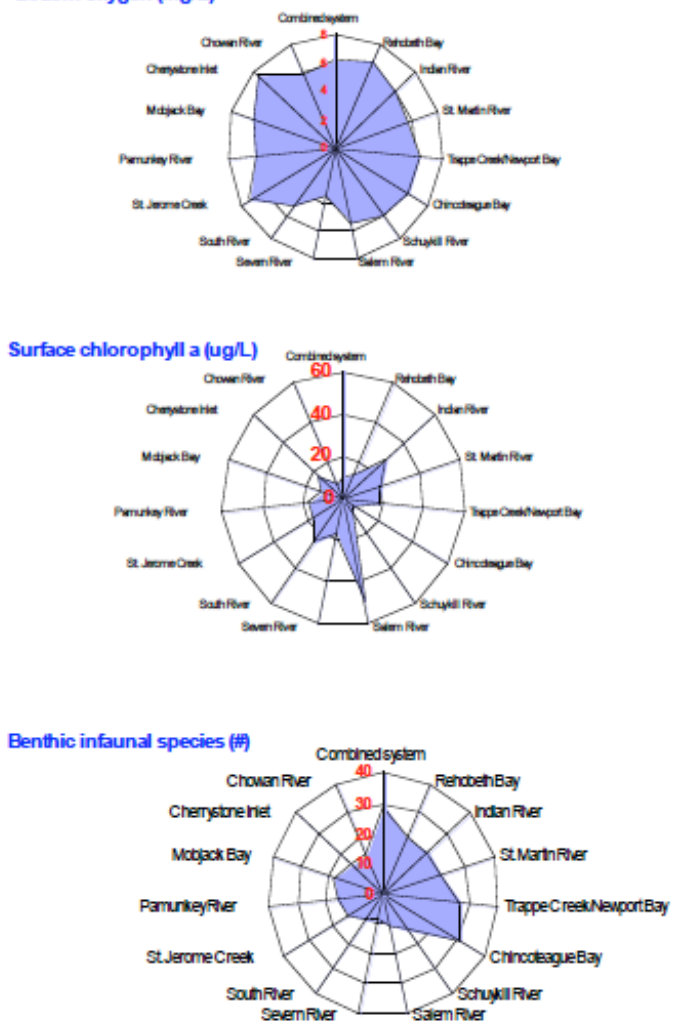

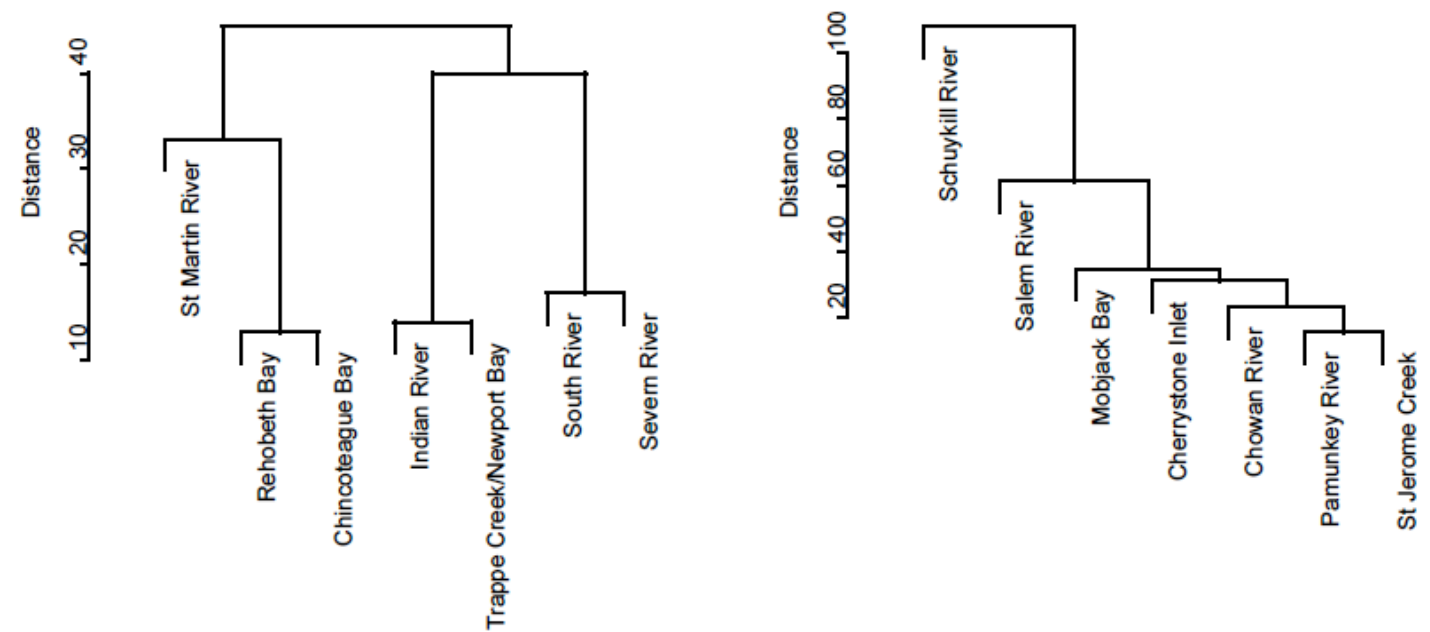

Fig. (3). Results of agglomerative hierarchical cluster analysis on mean values.
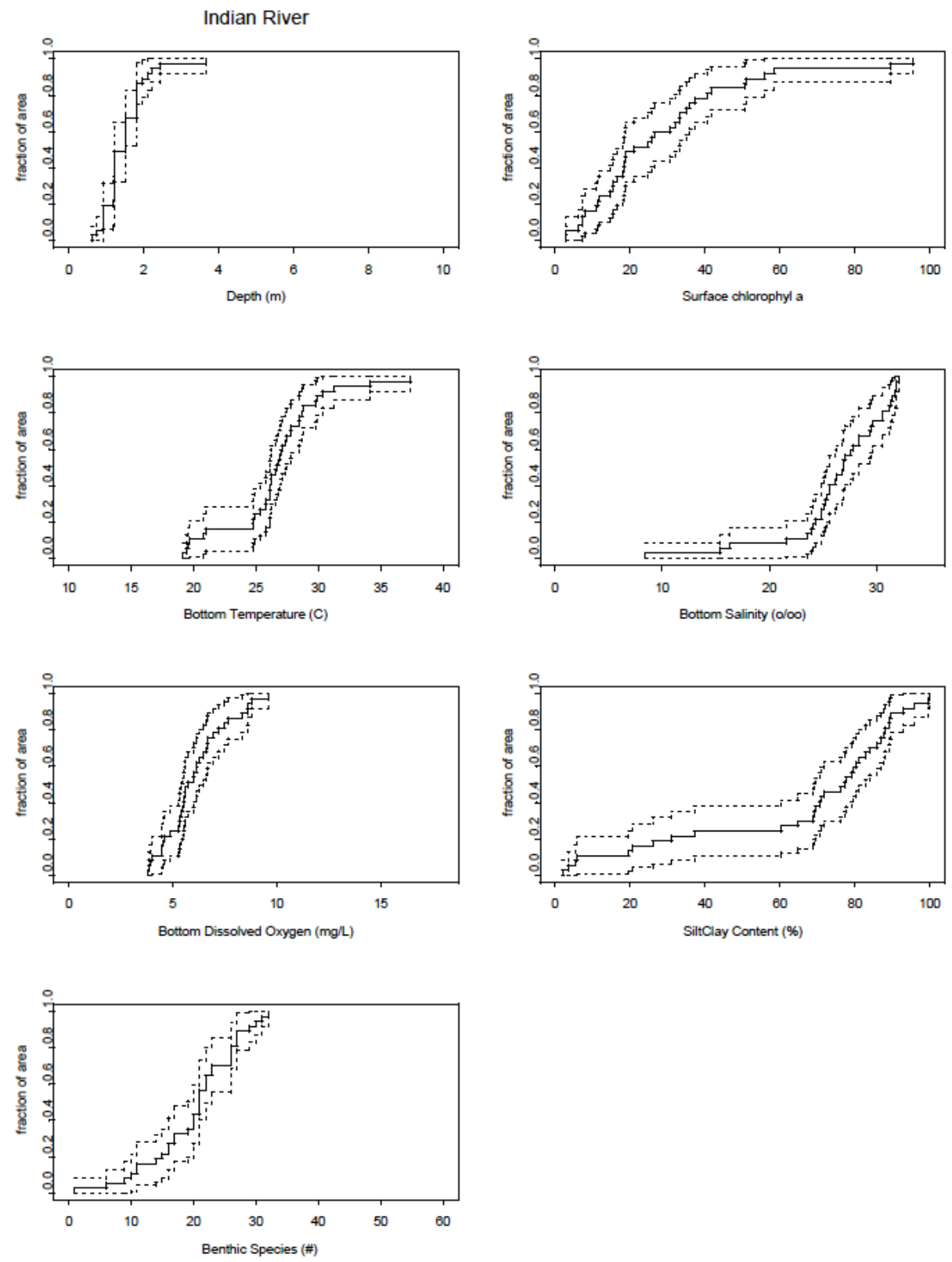

Fig. (4a). Cumulative distribution functions (CDFs) for Indian River. Dotted lines are 95\% confidence limits. 

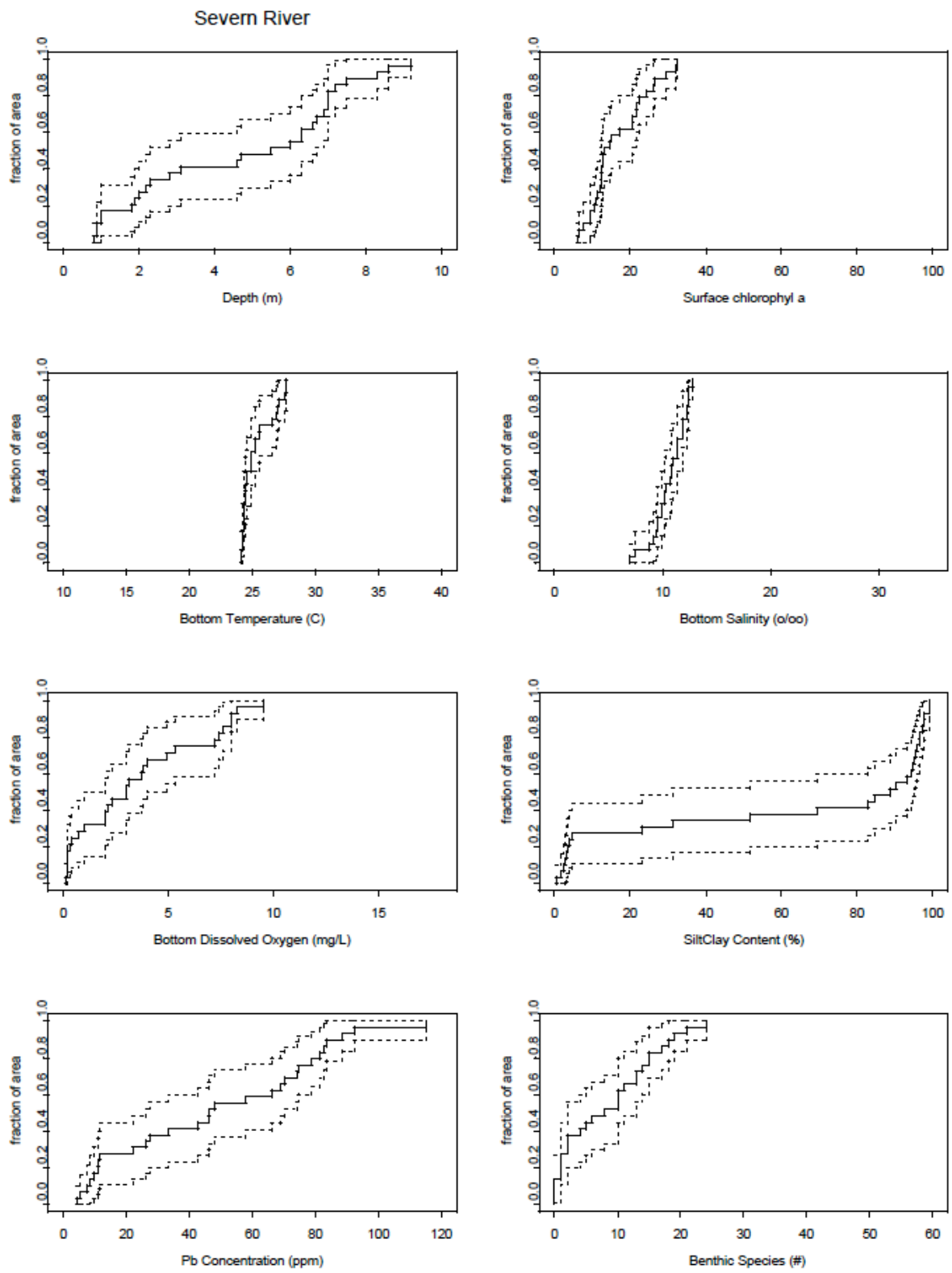

Fig. (4b). Cumulative distribution functions (CDFs) for Severn River. Dotted lines are 95\% confidence limits.

Table 4. Results of t-Tests between Systems for Selected Variables. Level of Statistical Significance is $p=0.05$. a) Significance of tTests. b) Number of Statistically Significant Differences between Systems

\begin{tabular}{|c|c|c|c|c|c|c|c|}
\hline a) depth & $\begin{array}{c}\text { Rehobeth } \\
\text { Bay }\end{array}$ & $\begin{array}{c}\text { Indian } \\
\text { River }\end{array}$ & $\begin{array}{l}\text { St. Martins } \\
\text { River }\end{array}$ & $\begin{array}{c}\text { Trappe Creek / } \\
\text { Newport Bay }\end{array}$ & $\begin{array}{c}\text { Chincoteague } \\
\text { Bay }\end{array}$ & $\begin{array}{l}\text { Severn } \\
\text { River }\end{array}$ & $\begin{array}{l}\text { South } \\
\text { River }\end{array}$ \\
\hline Indian River & NA & & & & & & \\
\hline St. Martins River & NA & NA & & & & & \\
\hline Trappe Creek/Newport Bay & 0.0115 & NA & 0.0010 & & & & \\
\hline Severn River & $<.0001$ & $<.0001$ & $<.0001$ & $<.0001$ & $<.0001$ & & \\
\hline South River & $<.0001$ & $<.0001$ & $<.0001$ & $<.0001$ & $<.0001$ & 0.0103 & \\
\hline combined system & 0.0085 & NA & 0.0082 & NA & NA & $<.0001$ & $<.0001$ \\
\hline Temperature & & & & & & & \\
\hline
\end{tabular}


Table 4. contd....

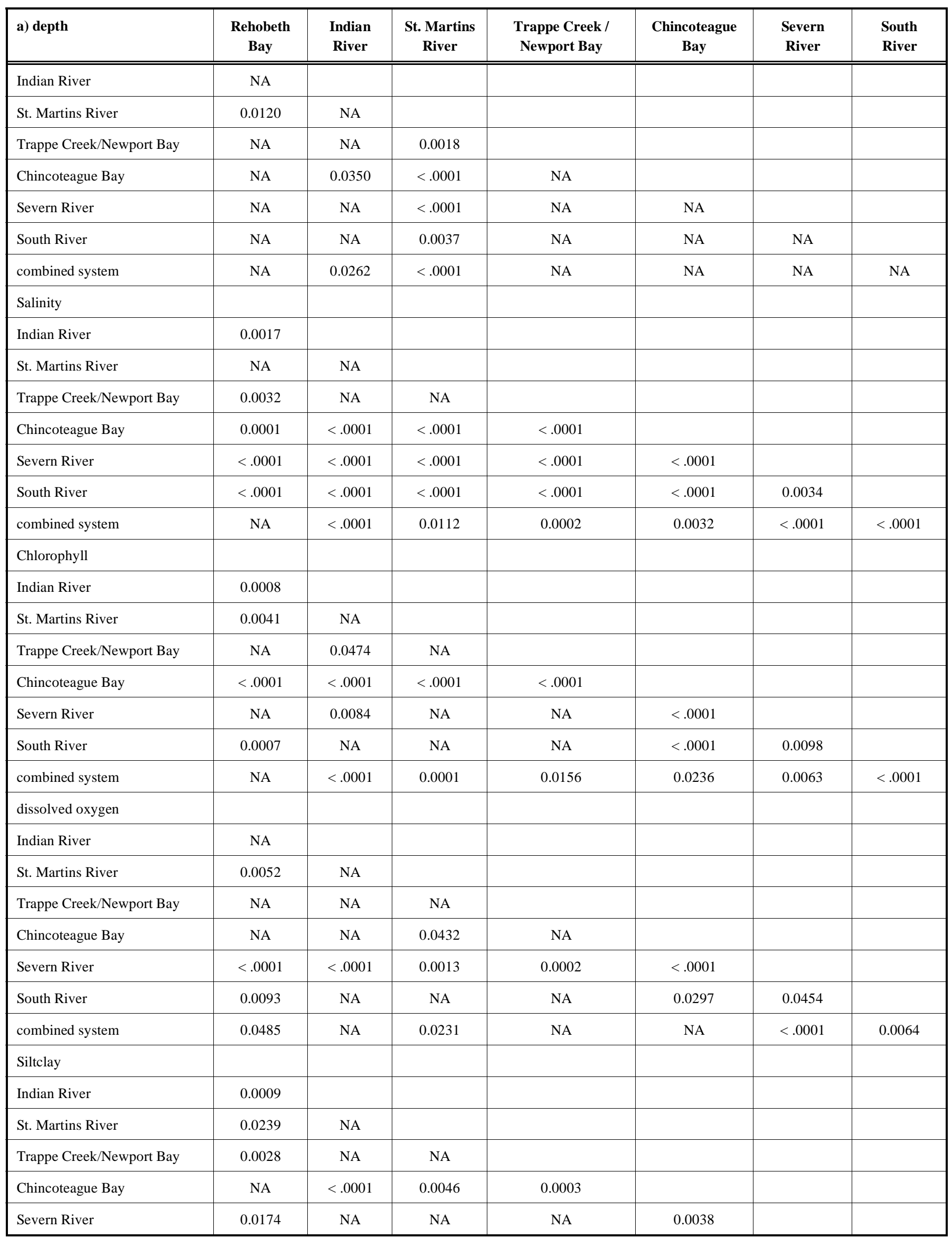


Table 4. contd....

\begin{tabular}{|c|c|c|c|c|c|c|c|}
\hline a) depth & $\begin{array}{c}\text { Rehobeth } \\
\text { Bay }\end{array}$ & $\begin{array}{l}\text { Indian } \\
\text { River }\end{array}$ & $\begin{array}{l}\text { St. Martins } \\
\text { River }\end{array}$ & $\begin{array}{l}\text { Trappe Creek / } \\
\text { Newport Bay }\end{array}$ & $\begin{array}{c}\text { Chincoteague } \\
\text { Bay }\end{array}$ & $\begin{array}{l}\text { Severn } \\
\text { River }\end{array}$ & $\begin{array}{l}\text { South } \\
\text { River }\end{array}$ \\
\hline South River & 0.0394 & NA & NA & NA & 0.0110 & NA & \\
\hline combined system & NA & 0.0038 & NA & 0.0107 & NA & 0.0465 & NA \\
\hline \multicolumn{8}{|l|}{ benthic species } \\
\hline St. Martins River & NA & NA & & & & & \\
\hline Trappe Creek/Newport Bay & 0.0052 & 0.0014 & 0.0256 & & & & \\
\hline Chincoteague Bay & $<.0001$ & $<.0001$ & $<.0001$ & NA & & & \\
\hline Severn River & $<.0001$ & $<.0001$ & $<.0001$ & $<.0001$ & $<.0001$ & & \\
\hline combined system & \multicolumn{7}{|c|}{$\mathrm{NA}=$ not significant at $\mathrm{p}=0.05$} \\
\hline $\begin{array}{l}\text { b) number of significant differ- } \\
\text { ences, } p=.05\end{array}$ & $\begin{array}{l}\text { Rehobeth } \\
\text { Bay }\end{array}$ & $\begin{array}{l}\text { Indian } \\
\text { River }\end{array}$ & $\begin{array}{l}\text { St. Martins } \\
\text { River }\end{array}$ & $\begin{array}{c}\text { Trappe Creek / New- } \\
\text { port Bay }\end{array}$ & $\begin{array}{c}\text { Chincoteague } \\
\text { Bay }\end{array}$ & Severn River & South River \\
\hline Indian River & 3 & & & & & & \\
\hline St. Martins River & 4 & 0 & & & & & \\
\hline Trappe Creek/Newport Bay & 4 & 2 & 3 & & & & \\
\hline Chincoteague Bay & 4 & 5 & 7 & 3 & & & \\
\hline Severn River & 5 & 5 & 5 & 4 & 6 & & \\
\hline
\end{tabular}

Table 5. Results of Kolmogorof-Smirnov Test for Difference in Distribution between Systems for Selected Variables. Level of Statistical Significance is $\mathbf{p}=\mathbf{0 . 0 5}$. a) Significance of Tests. b) Number of Statistically Significant Differences between Systems

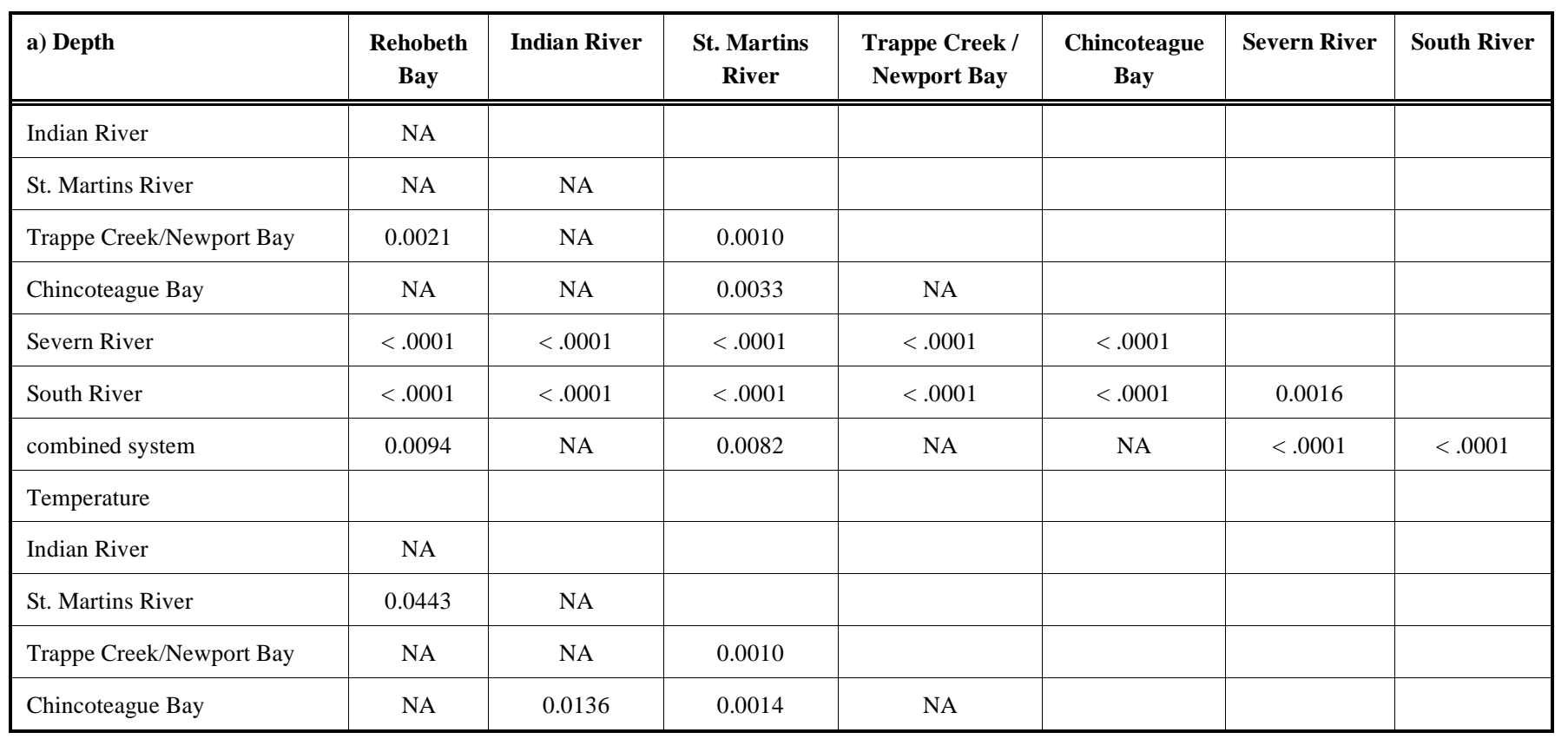


Table 5. contd....

\begin{tabular}{|c|c|c|c|c|c|c|c|}
\hline a) Depth & $\begin{array}{c}\text { Rehobeth } \\
\text { Bay }\end{array}$ & Indian River & $\begin{array}{l}\text { St. Martins } \\
\text { River }\end{array}$ & $\begin{array}{l}\text { Trappe Creek / } \\
\text { Newport Bay }\end{array}$ & $\begin{array}{c}\text { Chincoteague } \\
\text { Bay }\end{array}$ & Severn River & South River \\
\hline Severn River & NA & 0.0256 & 0.0009 & NA & 0.0281 & & \\
\hline South River & NA & 0.0007 & $<.0001$ & 0.0423 & 0.0463 & 0.0423 & \\
\hline combined system & NA & 0.0151 & 0.0082 & NA & NA & 0.0458 & 0.0460 \\
\hline Indian River & 0.0002 & & & & & & \\
\hline St. Martins River & NA & NA & & & & & \\
\hline Trappe Creek/Newport Bay & 0.0008 & NA & 0.0010 & & & & \\
\hline Chincoteague Bay & $<.0001$ & $<.0001$ & $<.0001$ & $<.0001$ & & & \\
\hline combined system & 0.0155 & 0.0008 & 0.0082 & 0.0010 & 0.0082 & $<.0001$ & $<.0001$ \\
\hline \multicolumn{8}{|l|}{ chlorophyll } \\
\hline Indian River & 0.0043 & & & & & & \\
\hline St. Martins River & 0.0001 & 0.0381 & & & & & \\
\hline Trappe Creek/Newport Bay & NA & 0.0120 & 0.0010 & & & & \\
\hline Chincoteague Bay & 0.0004 & $<.0001$ & $<.0001$ & $<.0001$ & & & \\
\hline Severn River & 0.0101 & NA & NA & 0.0175 & $<.0001$ & & \\
\hline South River & NA & 0.0255 & 0.0022 & NA & $<.0001$ & NA & \\
\hline Trappe Creek/Newport Bay & NA & NA & 0.0010 & & & & \\
\hline Chincoteague Bay & NA & 0.0325 & NA & NA & & & \\
\hline Severn River & 0.0003 & 0.0323 & NA & 0.0005 & 0.0005 & & \\
\hline South River & $<.0001$ & $<.0001$ & $<.0001$ & $<.0001$ & $<.0001$ & 0.0205 & \\
\hline combined system & NA & 0.0233 & 0.0082 & NA & NA & $<.0001$ & $<.0001$ \\
\hline \multicolumn{8}{|l|}{ siltclay } \\
\hline Indian River & 0.0031 & & & & & & \\
\hline St. Martins River & 0.0048 & NA & & & & & \\
\hline Trappe Creek/Newport Bay & 0.0054 & NA & 0.0010 & & & & \\
\hline Chincoteague Bay & NA & $<.0001$ & 0.0066 & 0.0015 & & & \\
\hline Severn River & 0.0302 & NA & 0.0260 & NA & 0.0023 & & \\
\hline South River & 0.0035 & 0.0145 & 0.0057 & 0.0195 & 0.0003 & NA & \\
\hline combined system & NA & 0.0022 & 0.0082 & 0.0464 & NA & 0.0148 & 0.0010 \\
\hline \multicolumn{8}{|l|}{ benthic species } \\
\hline Indian River & NA & & & & & & \\
\hline
\end{tabular}


Table 5. contd....

\begin{tabular}{|c|c|c|c|c|c|c|c|}
\hline a) Depth & $\begin{array}{c}\text { Rehobeth } \\
\text { Bay }\end{array}$ & Indian River & $\begin{array}{l}\text { St. Martins } \\
\text { River }\end{array}$ & $\begin{array}{l}\text { Trappe Creek / } \\
\text { Newport Bay }\end{array}$ & $\begin{array}{c}\text { Chincoteague } \\
\text { Bay }\end{array}$ & Severn River & South River \\
\hline St. Martins River & NA & NA & & & & & \\
\hline Trappe Creek/Newport Bay & 0.0239 & 0.0014 & 0.0010 & & & & \\
\hline Chincoteague Bay & $<.0001$ & $<.0001$ & 0.0022 & NA & & & \\
\hline South River & $<.0001$ & $<.0001$ & 0.0003 & $<.0001$ & $<.0001$ & NA & \\
\hline \multirow[t]{2}{*}{ combined system } & $<.0001$ & $<.0001$ & 0.0082 & NA & NA & $<.0001$ & $<.0001$ \\
\hline & \multicolumn{7}{|c|}{$\mathrm{NA}=$ not significant at $\mathrm{p}=0.05$} \\
\hline $\begin{array}{l}\text { b) Number of significant dif- } \\
\text { ferences at } p=0.05\end{array}$ & $\begin{array}{l}\text { Rehobeth } \\
\text { Bay }\end{array}$ & Indian River & $\begin{array}{l}\text { St. Martins } \\
\text { River }\end{array}$ & $\begin{array}{l}\text { Trappe Creek / } \\
\text { Newport Bay }\end{array}$ & $\begin{array}{l}\text { Chincoteague } \\
\text { Bay }\end{array}$ & Severn River & South River \\
\hline Trappe Creek/Newport Bay & 4 & 2 & 4 & & & & \\
\hline Chincoteague Bay & 3 & 6 & 6 & 3 & & & \\
\hline Severn River & 6 & 5 & 5 & 5 & 7 & & \\
\hline South River & 5 & 7 & 7 & 6 & 7 & 4 & \\
\hline combined system & 3 & 6 & 5 & 3 & 2 & 7 & 7 \\
\hline
\end{tabular}

statistically significantly different except for the one variable noted:

Indian River and Trappe Creek/Newport Bay except for number of benthic species,

St. Martins River and Trappe Creek/Newport Bay except for chlorophyll $a$,

South and Severn Rivers except for depth, and

Chincoteague Bay and combined system except for salinity.

If the data were normally distributed and equally variant then Tables $\mathbf{4}$ and $\mathbf{5}$ would be completely redundant. Differences noted between the tables are indicative of nonnormality in the data.

Spearman rank correlations $(\rho)$ between variables for each system are shown in Table 6. Severn River exhibited the most statistically significant correlations between variables, while Chincoteague Bay and Indian River have the least for the systems with a minimum of 23 sites. Not only did Severn River have the most significant correlations, but also the correlations were among the strongest. Very few significant correlations were exhibited in systems with small number of sites. Salinity and chlorophyll $a$ were the variables with significant correlations in the most systems with a minimum of 23 sites, all systems except the Severn River.

The results of the tests for difference in correlation matrices between systems were that the following systems were not statistically significantly different at 0.05 significance level: Rehobeth Bay, Indian River, Trappe Creek/Newport Bay, Chincoteague Bay, South River, and combined system.
The outliers were Severn River, which was not statistically significantly different to any of the other systems, and St. Martins River, which was not statistically significantly different from only Trappe Creek/Newport Bay and South River. It should be noted that we were only demonstrating a possible way to analyze these data. We were in fact exploring the data sets for differences and were not worrying about experiment-wise error rates.

Fractional area CDFs for variables with $95 \%$ confidence intervals for two systems (Severn River and Indian River) are presented in Fig. (4) as examples of the method. The variables with lower $\mathrm{CV}$ s correspond with reasonably tight CDFs. CDFs for bottom dissolved oxygen and number of benthic species for all of the systems are shown in Fig. (5). The CDFs in the figure can be used to pick off fractional area below a defined threshold for the variable that represents a biologically significant criterion. For example, values of 2 and $5 \mathrm{mg} / \mathrm{L}$ are commonly used as criteria for bottom dissolved oxygen (DO) concentrations. From Fig. (5), South and Severn Rivers are systems with the larger fractional area impacted with moderate hypoxia (DO $<5 \mathrm{mg} / \mathrm{L}$ ), $55 \%$ and $77 \%$, respectively. CDFs appear to be an effective analysis tool to capture the distribution for a variable in the small systems, even for those with a small number of sites.

Contours for two systems (Severn and Indian Rivers) using bivariate interpolation are shown in Fig. (6). Contours for bottom dissolved oxygen and number of benthic species for the systems with at least 23 sites are shown in Fig. (7). This characterization method provides information on the spatial distribution of the variables for the individual systems, but no information on uncertainty for the estimated values. 
Table 6. Statistically Significant $(p \leq 0.05)$ Spearman Rank Correlations $(\rho)$ between Variables in Each System. ““_“ Indicates $\rho$ not Considered Statistically Significant

Rehobeth Bay

$\begin{array}{lcccc} & \text { depth } & \text { temp } & \text { salin } & \text { ch } \\ \text { depth } & 1.00 & - & - & - \\ \text { temp } & - & 1.00 & -0.55 & 0.41 \\ \text { salin } & - & -0.55 & 1.00 & -0.84 \\ \text { chla } & - & 0.41 & -0.84 & 1.00 \\ \text { do } & - & - & - & 0.34 \\ \text { sicl } & 0.51 & 0.39 & -0.46 & 0.40 \\ \text { species } & - & - & - & -0.36\end{array}$

St. Martins River

$\begin{array}{lccccccc} & \text { depth } & \text { temp } & \text { salin } & \text { chla } & \text { do } & \text { sicl } & \text { species } \\ \text { depth } & 1.00 & - & 0.64 & -0.57 & - & - & 0.48 \\ \text { temp } & - & 1.00 & - & - & - & - & -0.36 \\ \text { salin } & 0.64 & - & 1.00 & -0.50 & 0.42 & - & 0.76 \\ \text { chla } & -0.57 & - & -0.50 & 1.00 & - & 0.39 & -0.61 \\ \text { do } & - & - & 0.42 & - & 1.00 & - & - \\ \text { sicl } & - & - & - & 0.39 & - & 1.00 & - \\ \text { species } & 0.48 & -0.36 & 0.76 & -0.61 & - & - & 1.00\end{array}$

Chincoteague Bay

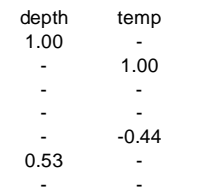

$$
\begin{array}{cc}
\text { salin } & \text { chla } \\
- & - \\
- & - \\
1.00 & -0.49 \\
-0.49 & 1.00 \\
0.36 & - \\
- & - \\
0.27 & -
\end{array}
$$

Severn River

$\begin{array}{ccccccc}\text { depth } & \text { temp } & \text { salin } & \text { chla } & \text { do } & \text { sicl } & \text { species } \\ 1.00 & -0.72 & 0.77 & - & -0.79 & 0.61 & -0.66 \\ -0.72 & 1.00 & -0.42 & - & 0.93 & -0.65 & 0.88 \\ 0.77 & -0.42 & 1.00 & - & -0.46 & 0.57 & -0.37 \\ - & - & - & 1.00 & - & - & - \\ -0.79 & 0.93 & -0.46 & - & 1.00 & -0.58 & 0.86 \\ 0.61 & -0.65 & 0.57 & - & -0.58 & 1.00 & -0.52\end{array}$

Indian River

$\begin{array}{ccccccc}\text { depth } & \text { temp } & \text { salin } & \text { chla } & \text { do } & \text { sicl } & \text { species } \\ 1.00 & - & 0.37 & - & - & 0.45 & 0.30 \\ - & 1.00 & -0.54 & 0.70 & - & - & - \\ 0.37 & -0.54 & 1.00 & -0.70 & - & - & - \\ - & 0.70 & -0.70 & 1.00 & - & - & - \\ - & - & - & - & 1.00 & - & - \\ 0.45 & - & - & - & - & 1.00 & - \\ 0.30 & - & - & - & - & - & 1.00\end{array}$

Trappe Creek/Newport Bay

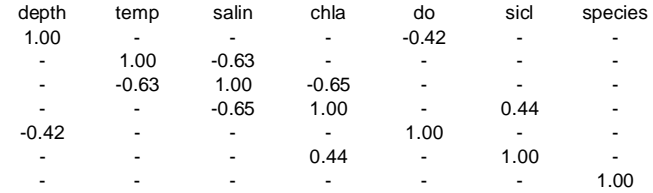

South River

$\begin{array}{ccccccc}\text { depth } & \text { temp } & \text { salin } & \text { chla } & \text { do } & \text { sicl } & \text { species } \\ 1.00 & - & 0.51 & - & -0.51 & 0.73 & -0.70 \\ - & 1.00 & -0.67 & - & - & - & - \\ 0.51 & -0.67 & 1.00 & -0.43 & - & - & - \\ - & - & -0.43 & 1.00 & - & - & - \\ -0.51 & - & - & - & 1.00 & -0.61 & 0.65 \\ 0.73 & - & - & - & -0.61 & 1.00 & -0.85 \\ -0.70 & - & - & - & 0.65 & -0.85 & 1.00\end{array}$

\section{combined system}

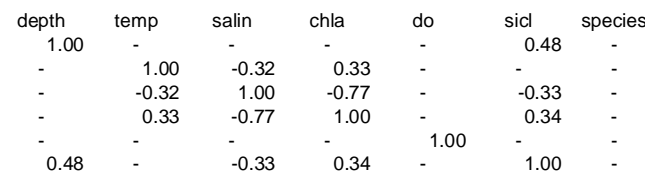

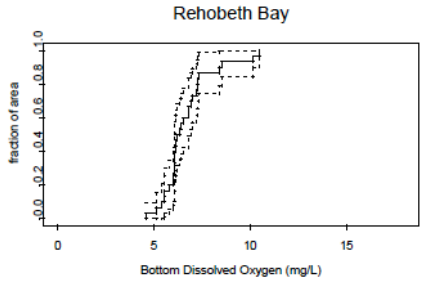
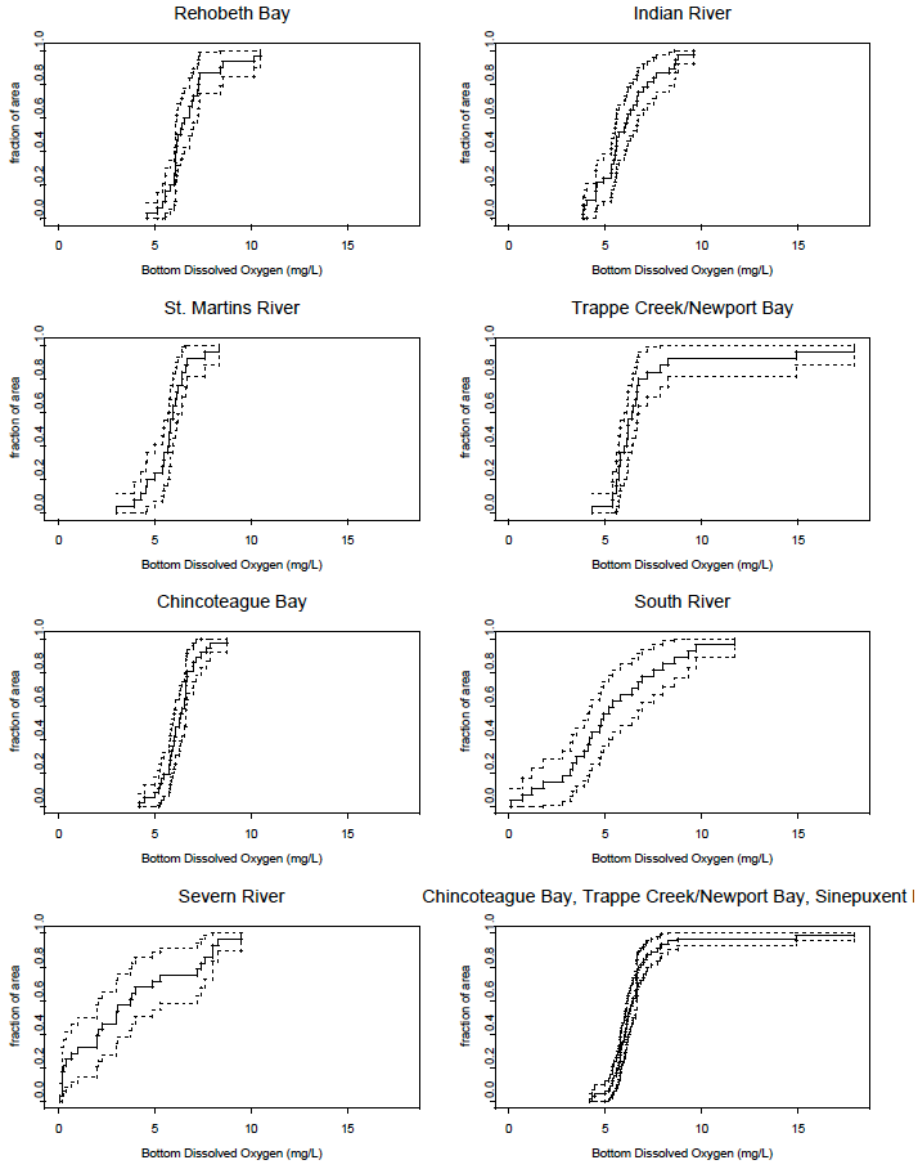

Fig. (5a). Bottom dissolved oxygen CDFs for small estuarine systems. Dotted lines are $95 \%$ confidence limits. 

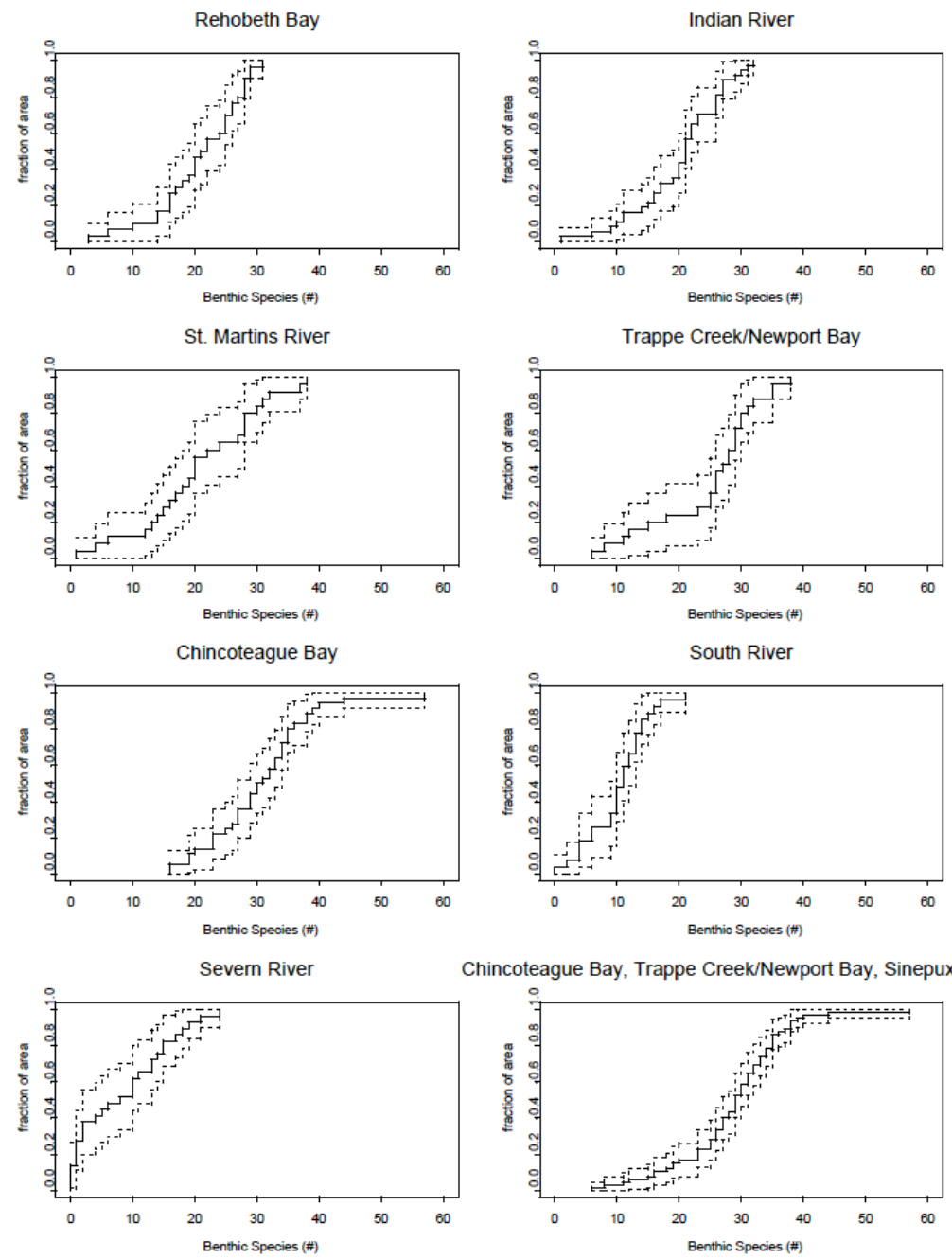

Chincoteague Bay, Trappe Creek/Newport Bay, Sinepuxent

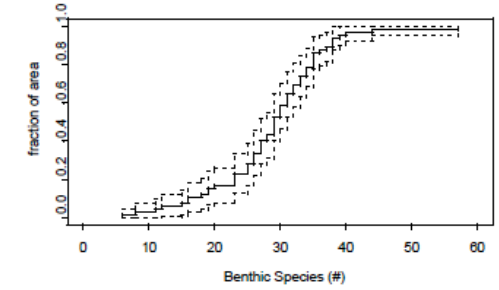

Fig. (5b). Number of benthic species CDFs for small estuarine systems. Dotted lines are 95\% confidence limits.

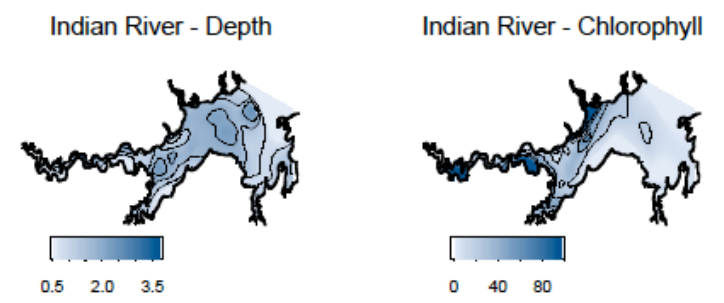

Indian River - Bottom Temperature

Indian River - Bottom Salinity Indian River - Bottom Dissolved Oxygen
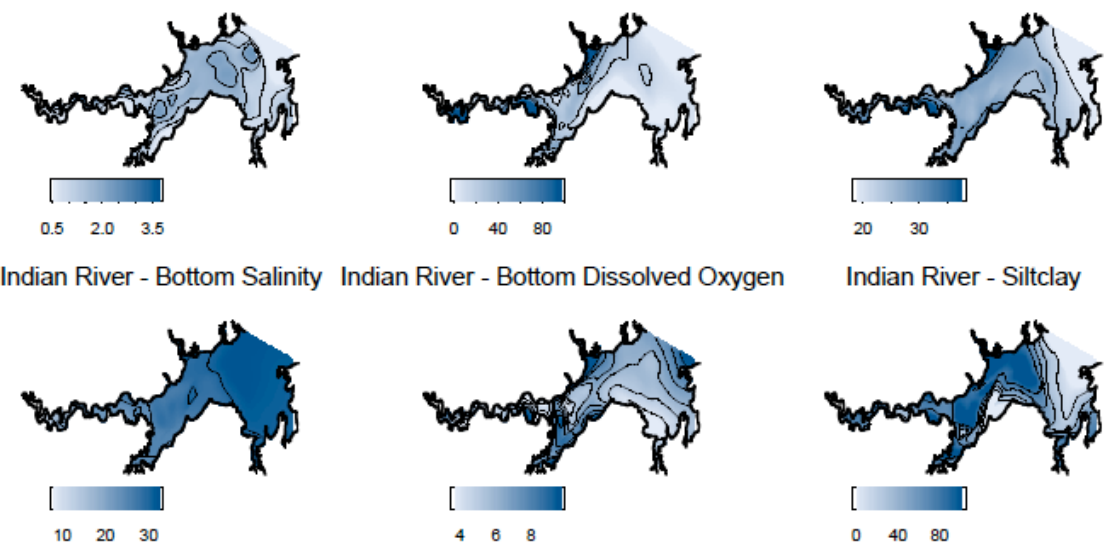

Indian River - Siltclay

Indian River - Benthic Species

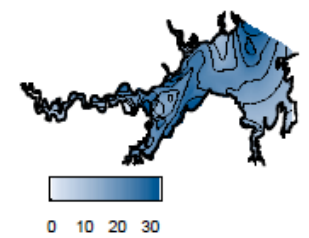

Fig. (6a). Contours for Indian River using bivariate interpolation of measured values. 


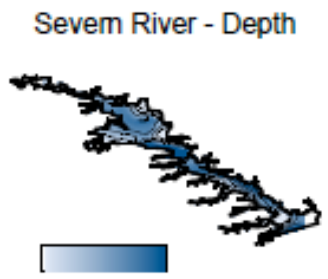

24468
Sevem River - Chlorophyll

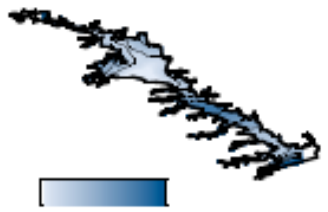

$\begin{array}{lll}5 & 15 & 25\end{array}$
Severn River - Bottom Temperature

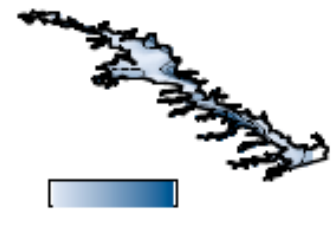

$24 \quad 26$

Severn River - Siltclay

Severn River - Bottom Salinity Sevem River - Bottom Dissolved Oxygen

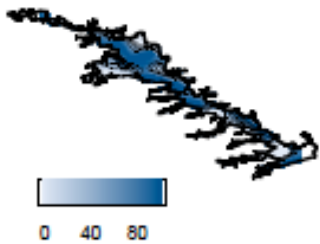

Sevem River - Benthic Species

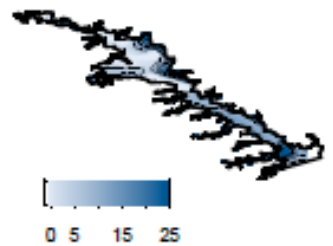

Fig. (6b). Contours for Severn River using bivariate interpolation of measured values.

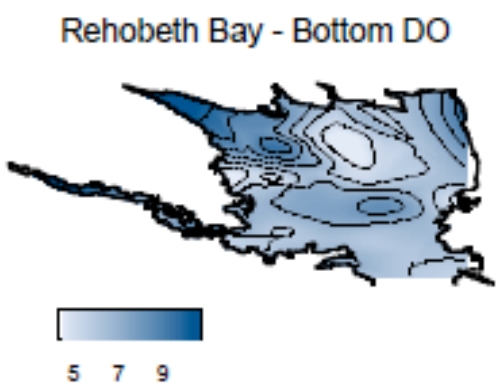

St. Martins River - Bottom DO

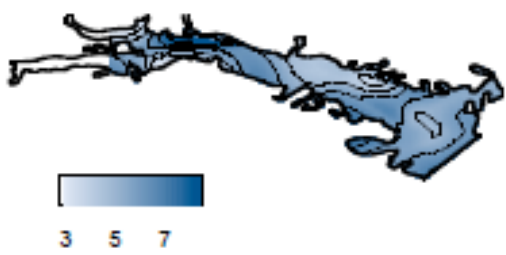

South River - Bottom DO

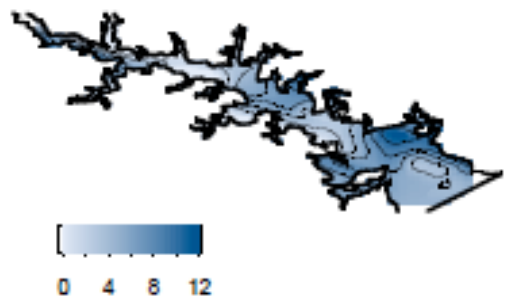

Indian River - Bottom DO

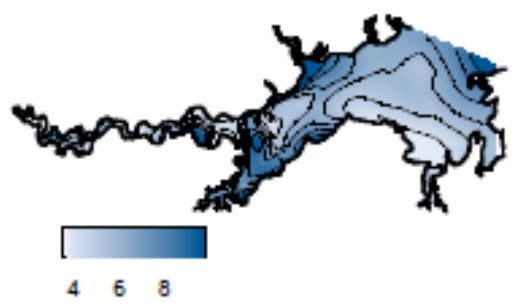

Chincoteague Bay - Bottom DO

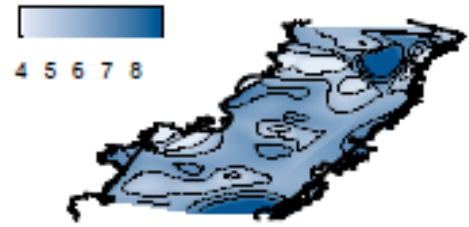

Severn River - Bottom DO

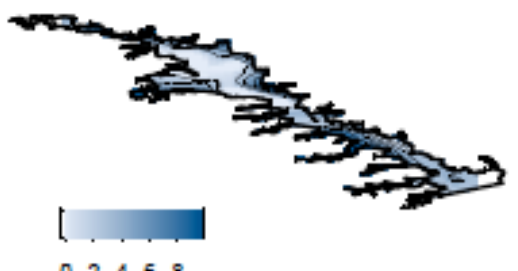

Fig. (7a). Contours for bottom dissolved oxygen from bivariate interpolation for small estuarine systems. 


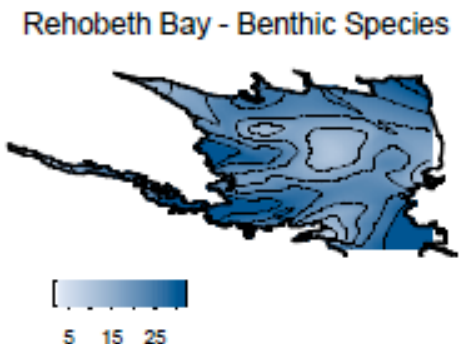

Chincoteague Bay - Benthic Species

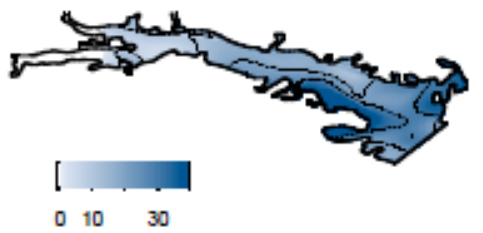

South River - Benthic Species

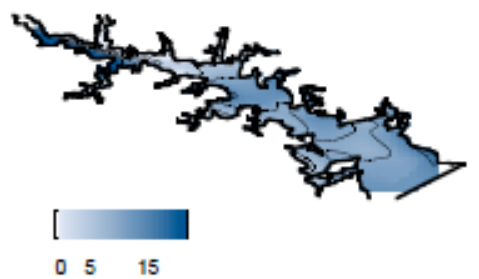

Indian River - Benthic Species

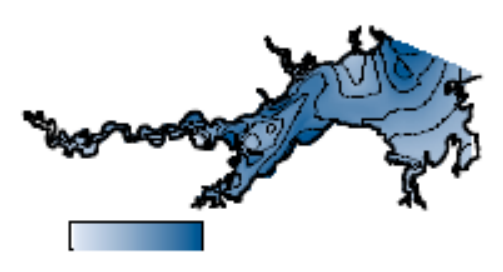

$\begin{array}{llll}0 & 10 & 20 & 30\end{array}$

Chincoteague Bay - Benthic Species

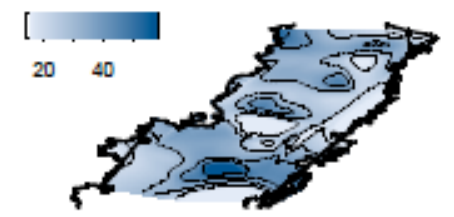

Sevem River - Benthic Species

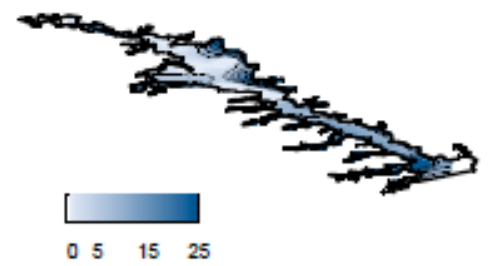

Fig. (7b). Contours for number of benthic species from bivariate interpolation for small estuarine systems.

\section{Kriging Results}

The attributes of the constructed variograms for the residuals are summarized in Table 7. From the overall kriging process, a large portion of the variation for each variable was accounted for by the trend component (loess model), expressed in Table 7 by percent variance (of the total variance) explained by the loess model. Examples of the variograms are shown in Fig. (8). Variograms categorized into the spherical and exponential forms indicate that the variables had good continuity in space. Pure nugget variograms indicate no spatial correlation for the residuals. For some variables, the nugget effect, representing experimental error and field variation within the minimum sampling spacing, was sometimes quite large compared to the sill, which represents total spatial variation. The ratio of nugget variance to total variance expressed in percentages can be regarded as a criterion to classify the spatial dependence of the variables [16]. If the ratio is less than $25 \%$, the variable has strong spatial dependence, between 25 and $75 \%$, the variable has moderate spatial dependence, and greater than $75 \%$, the variable shows only weak spatial dependence [33].

The kriging results indicated weak spatial dependence for almost all variables in the individual coastal bays, while there was moderate and strong spatial dependence for some variables in South and Severn Rivers and the combined system. Strong spatial dependence was exhibited for bottom temperature in both the South and Severn Rivers. For the coastal bays, there was weak spatial dependence in the variograms of the residuals after removal of the spatial trend with a loess model. There was a spatial dependence reflected in the trend components, although a spatial correlation does not appear in the variograms for the residuals. The variables with pure nugget variograms were indicative of little or no spatial dependency. Therefore, kriging has no significant advantage for interpolating these variables.

\section{Effect of Sample Size on Kriging Estimates}

The RMSE was used to express the extent of agreement between the actual and kriged estimate values from the randomization simulations for evaluation of the effect of sample size. Spearman rank correlation coefficients indicated the degree that spatial information was maintained when fewer samples were used for estimation compared to values of estimates from the maximum sample size. The RMSE and correlation coefficients for the variables from the three systems as a function of sample size are listed in Table 8. Results indicated strong correlations for reduced sample sizes greater than 25, with comparable RMSE for all three systems. Below 25 samples, the results began to deviate (correlation below 0.8 ). Reduced sample size, as long as $\mathrm{N}_{\mathrm{S}}>25$, seemed to have minimal effect on the characterization results. Sample sizes of 25-30 were adequate to spatially characterize the individual estuarine systems. It should be noted that the systematic grid sampling used is optimal sampling for spatial estimation. This contributes to the good results for small sample sizes.

\section{Evaluation of Interpolation Methods}

The results of the comparison of interpolation methods are shown in Table 9. Results were expressed as mean square error (MSE) of prediction. The kriged MSEs were much lower than the bivariate interpolation MSEs for the combined system, which exhibited the most spatial correlation. 
Table 7. Summary of Variogram Attributes for Residuals of Variables in Each System with Spatial Trend Removed with Loess Model. Fitted Variogram Parameters: Range $=r$, Sill or Total Variance $=C_{0}+C_{1}$, and Nugget Variance $=C_{0}$

\begin{tabular}{|c|c|c|c|c|c|c|c|}
\hline System & Variable & $\begin{array}{c}\text { Variogram } \\
\text { model }\end{array}$ & $\mathbf{r}(\mathbf{k m})$ & $\mathrm{C}_{0}+\mathrm{C}_{1}$ & $\mathbf{C}_{0}$ & Spatial dependence $\dagger$ & Loess/total $\ddagger$ \\
\hline \multirow[t]{7}{*}{ Rehobeth Bay } & depth & linear & & & 0.13 & ND & 0.50 \\
\hline & bottom temperature & pure nugget & & 3.53 & 3.53 & Weak & 0.85 \\
\hline & bottom salinity & spherical & 8.47 & 1.09 & 0.77 & Moderate & 0.37 \\
\hline & surface chlorophyll $a$ & pure nugget & & 211.9 & 211.98 & Weak & 0.84 \\
\hline & bottom oxygen & pure nugget & & 1.45 & 1.45 & Weak & 0.68 \\
\hline & sediment silt-clay & exponential & .58 & 477.8 & 188.41 & Moderate & 0.48 \\
\hline & benthic species & pure nugget & & 19.63 & 19.63 & Weak & 0.57 \\
\hline \multirow[t]{7}{*}{ Indian River } & depth & pure nugget & & 0.13 & 0.13 & Weak & 0.35 \\
\hline & bottom temperature & pure nugget & & 5.84 & 5.84 & Weak & 0.45 \\
\hline & bottom salinity & linear & & & 0.37 & ND & 0.68 \\
\hline & surface chlorophyll $a$ & pure nugget & & 15.36 & 15.36 & Weak & 0.94 \\
\hline & bottom oxygen & pure nugget & & 0.48 & 0.48 & Weak & 0.24 \\
\hline & sediment silt-clay & pure nugget & & 455.2 & 455.23 & Weak & 0.41 \\
\hline & benthic species & pure nugget & & 21.85 & 21.85 & Weak & 0.63 \\
\hline \multirow[t]{7}{*}{ St. Martin River } & depth & pure nugget & & 0.02 & 0.02 & Weak & 0.63 \\
\hline & bottom temperature & pure nugget & & 1.58 & 1.58 & Weak & 0.72 \\
\hline & bottom salinity & pure nugget & & 0.35 & 0.35 & Weak & 0.46 \\
\hline & surface chlorophyll $a$ & pure nugget & & 9.04 & 9.04 & Weak & 0.96 \\
\hline & bottom oxygen & pure nugget & & 0.47 & 0.47 & Weak & 0.33 \\
\hline & sediment silt-clay & pure nugget & & 379.9 & 379.92 & Weak & 0.42 \\
\hline & benthic species & pure nugget & & 22.01 & 22.01 & Weak & 0.71 \\
\hline \multirow[t]{7}{*}{ Trappe Creek/Newport Bay } & depth & linear & & & 0.02 & ND & 0.70 \\
\hline & bottom temperature & pure nugget & & 2.43 & 2.43 & Weak & 0.92 \\
\hline & bottom salinity & pure nugget & & 1.17 & 1.17 & Weak & 0.37 \\
\hline & surface chlorophyll $a$ & pure nugget & & 14.96 & 14.96 & Weak & 0.65 \\
\hline & bottom oxygen & pure nugget & & 0.37 & 0.37 & Weak & 0.46 \\
\hline & sediment silt-clay & pure nugget & & 492.5 & 492.51 & Weak & 0.46 \\
\hline & benthic species & linear & & & 5.14 & ND & 0.72 \\
\hline \multirow[t]{7}{*}{ Chincoteague Bay (MD) only) } & depth & pure nugget & & 0.07 & 0.07 & Weak & 0.69 \\
\hline & bottom temperature & pure nugget & & 5.45 & 5.45 & Weak & 0.37 \\
\hline & bottom salinity & pure nugget & & 1.71 & 1.71 & Weak & 0.12 \\
\hline & surface chlorophyll $a$ & pure nugget & & 10.96 & 10.96 & Weak & 0.66 \\
\hline & bottom oxygen & pure nugget & & 0.60 & 0.60 & Weak & 0.15 \\
\hline & sediment silt-clay & pure nugget & & 460.1 & 460.11 & Weak & 0.47 \\
\hline & benthic species & pure nugget & & 40.12 & 40.12 & Weak & 0.38 \\
\hline
\end{tabular}


Table 7. contd....

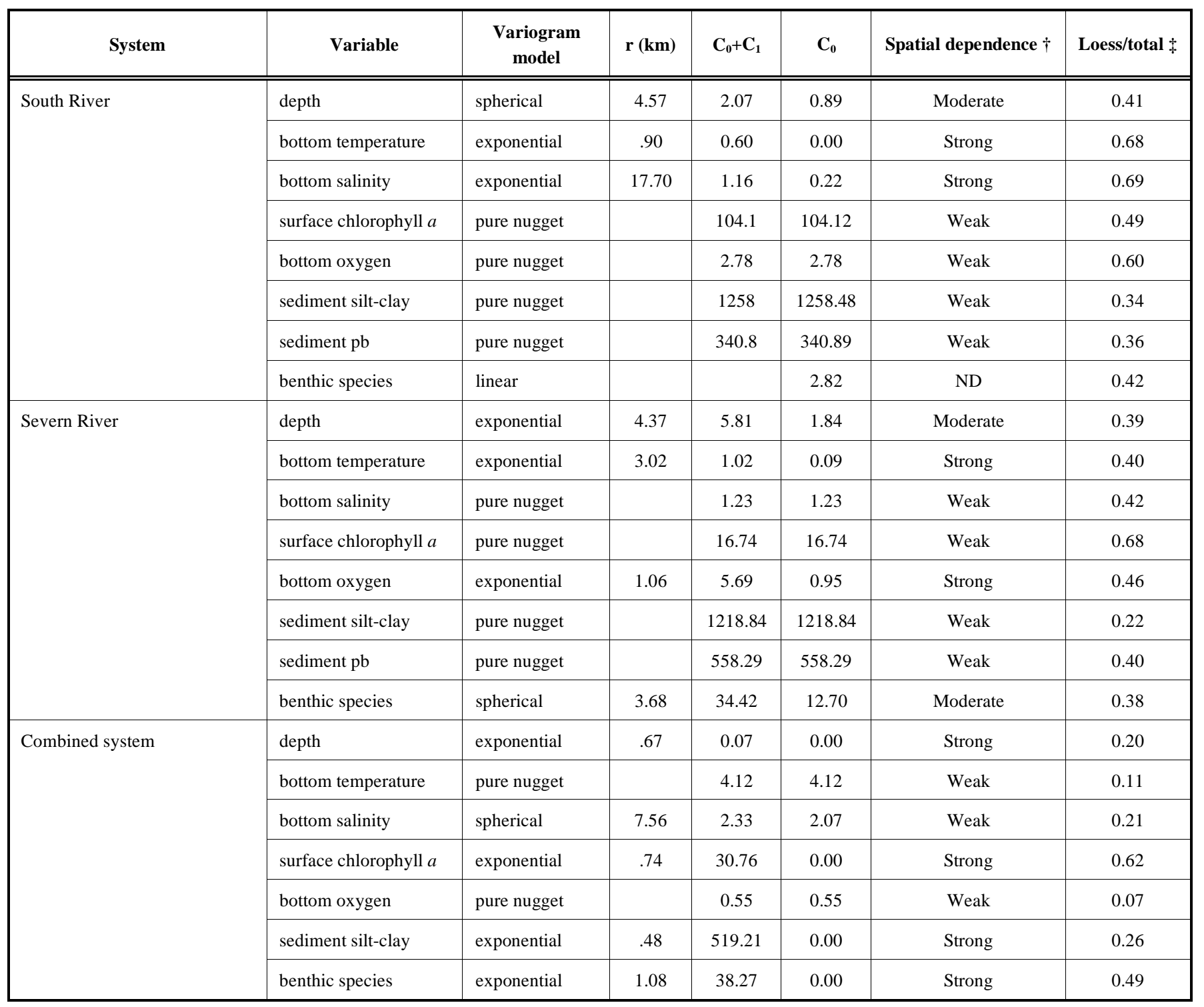

$\mathrm{ND}=$ not determined for linear variogram

$\dagger=$ ratio of nugget variance to variance: strong, $<25 \%$; moderate $25-75 \%$; weak, $>75 \%$

$\ddagger=$ fraction of variance explained by loess model

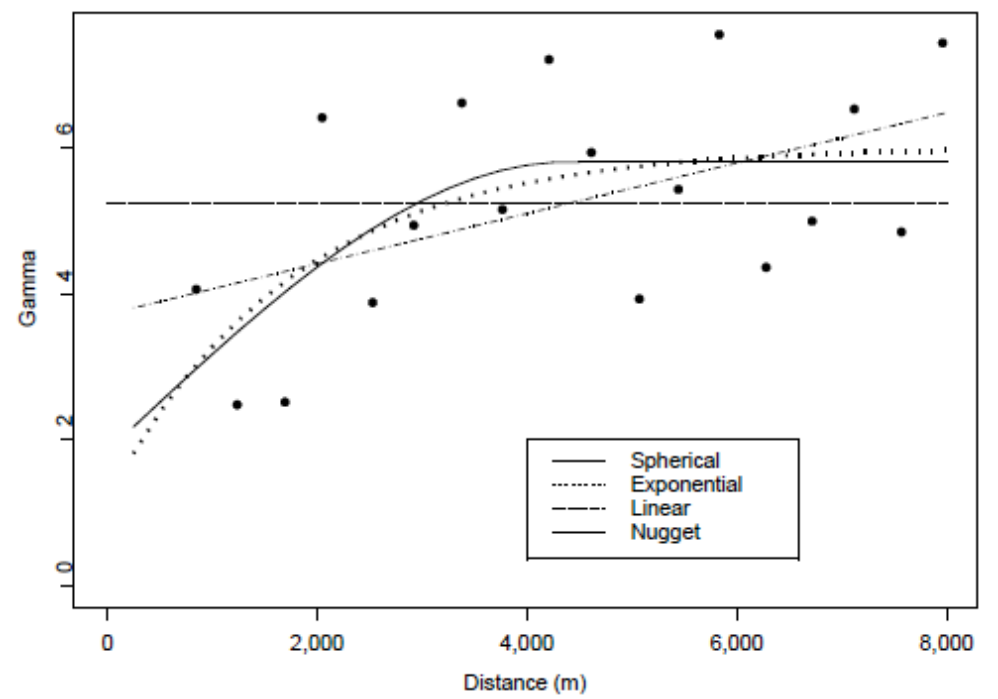

Fig. (8). Examples of variograms for the Severn River. (contd.....) 
Fig. (8). contd....
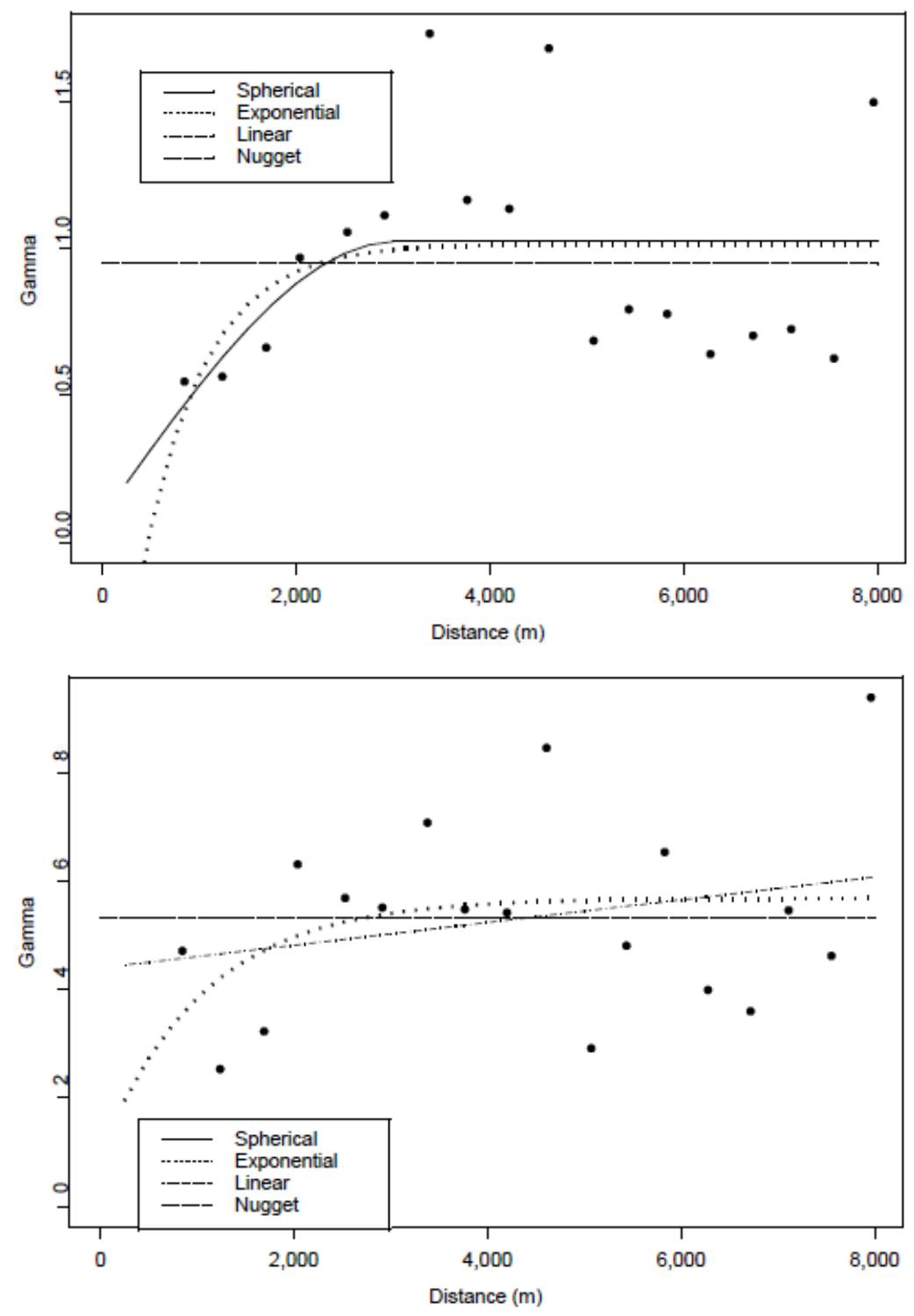

Fig. (8). Examples of variograms for the Severn River.

Table 8. Results from Evaluation of Sample Size $\left(\mathbf{N}_{S}\right)$ on Kriged Estimates for Indian River, Chincoteague Bay, and Combined System. Median Results of 100 Randomizations for Relative Mean Square Error (RMSE) and Spearman Rank Correlation. RMSE and Correlation are between Actual Values and Estimated Values for Reduced Sample Size

\begin{tabular}{|c|c|c|c|c|c|c|}
\hline \multirow[b]{2}{*}{ Indian River } & \multirow{2}{*}{$\begin{array}{c}\text { RMSE } \\
N_{S}=32\end{array}$} & \multirow[b]{2}{*}{$N_{S}=27$} & \multirow[b]{2}{*}{$\mathrm{N}_{\mathrm{S}}=22$} & \multicolumn{2}{|c|}{ Correlation } & \multirow[b]{2}{*}{$\mathrm{N}_{\mathrm{S}}=22$} \\
\hline & & & & $\mathrm{N}_{\mathrm{S}}=32$ & $\mathrm{~N}_{\mathrm{S}}=27$ & \\
\hline bottom temperature & 0.41 & 0.46 & 0.71 & 0.97 & 0.92 & 0.83 \\
\hline bottom salinity & 0.09 & 0.09 & 0.13 & 0.99 & 0.99 & 0.98 \\
\hline bottom oxygen & 1.02 & 1.02 & 1.48 & 0.91 & 0.83 & 0.66 \\
\hline sediment silt-clay & 0.86 & 1.09 & 1.17 & 0.91 & 0.79 & 0.69 \\
\hline benthic species & 0.56 & 0.67 & 0.73 & 0.94 & 0.85 & 0.77 \\
\hline
\end{tabular}


Table 8. contd....

\begin{tabular}{|c|c|c|c|c|c|c|c|c|}
\hline & RMSE & & & & \multicolumn{2}{|c|}{ Correlation } & & \\
\hline Chincoteague Bay & $\mathrm{N}_{\mathrm{S}}=31$ & $\mathrm{~N}_{S}=26$ & $N_{S}=21$ & & $\mathrm{~N}_{\mathrm{S}}=31$ & $N_{S}=26$ & $N_{S}=21$ & \\
\hline bottom temperature & 1.51 & 1.79 & 2.08 & & 0.89 & 0.77 & 0.56 & \\
\hline bottom salinity & 0.44 & 0.70 & 0.82 & & 0.97 & 0.91 & 0.84 & \\
\hline bottom oxygen & 1.33 & 1.61 & 1.98 & & 0.88 & 0.75 & 0.59 & \\
\hline sediment silt-clay & 0.66 & 0.86 & 1.03 & & 0.95 & 0.89 & 0.80 & \\
\hline benthic species & 0.99 & 1.16 & 1.43 & & 0.91 & 0.82 & 0.68 & \\
\hline Combined system & $\mathrm{N}_{\mathrm{S}}=53$ & $\mathrm{~N}_{\mathrm{S}}=43$ & $\mathrm{~N}_{\mathrm{S}}=33$ & $\mathrm{~N}_{\mathrm{S}}=23$ & $\mathrm{~N}_{\mathrm{S}}=53$ & $\mathrm{~N}_{\mathrm{S}}=43$ & $\mathrm{~N}_{\mathrm{S}}=33$ & $\mathrm{~N}_{\mathrm{S}}=23$ \\
\hline bottom salinity & 0.33 & 0.36 & 0.36 & 0.45 & 0.97 & 0.94 & 0.90 & 0.83 \\
\hline surface chlorophyll $a$ & 0.39 & 0.39 & 0.52 & 0.55 & 0.96 & 0.89 & 0.82 & 0.69 \\
\hline bottom oxygen & 1.13 & 1.20 & 1.39 & 1.60 & 0.88 & 0.74 & 0.56 & 0.39 \\
\hline sediment silt-clay & 0.78 & 0.81 & 0.82 & 1.07 & 0.94 & 0.87 & 0.80 & 0.68 \\
\hline benthic species & 0.91 & 1.12 & 1.08 & 1.26 & 0.90 & 0.79 & 0.67 & 0.50 \\
\hline
\end{tabular}

Table 9. Mean Square Error (MSE) Comparison of Kriging and Linear Interpolation Methods. MSE Determined by CrossValidation

\begin{tabular}{|c|c|c|c|c|}
\hline System & Variable & Kriging MSE & Linear interpolation MSE & Kriging MSE / linear MSE \\
\hline \multirow{4}{*}{ Rehobeth Bay } & bottom salinity & 1.87 & 1.80 & 1.04 \\
\hline & surface chlorophyll $a$ & 30.10 & 47.26 & 0.64 \\
\hline & sediment silt-clay & 908.95 & 1281.75 & 0.71 \\
\hline & benthic species & 43.40 & 62.60 & 0.69 \\
\hline \multirow[t]{5}{*}{ Indian River } & depth & 0.42 & 0.52 & 0.81 \\
\hline & bottom temperature & 7.70 & 13.60 & 0.57 \\
\hline & bottom oxygen & 2.54 & 2.49 & 1.02 \\
\hline & sediment silt-clay & 1027.17 & 925.15 & 1.11 \\
\hline & benthic species & 33.87 & 58.74 & 0.58 \\
\hline \multirow[t]{3}{*}{ St. Martin River } & depth & 0.09 & 0.08 & 1.19 \\
\hline & bottom temperature & 4.19 & 3.90 & 1.07 \\
\hline & bottom salinity & 0.76 & 1.05 & 0.73 \\
\hline
\end{tabular}


Table 9. contd....

\begin{tabular}{|c|c|c|c|c|}
\hline System & Variable & Kriging MSE & Linear interpolation MSE & Kriging MSE / linear MSE \\
\hline & surface chlorophyll $a$ & 37.02 & 37.98 & 0.97 \\
\hline & bottom oxygen & 4.09 & 1.68 & 2.44 \\
\hline & sediment silt-clay & 1686.46 & 1015.23 & 1.66 \\
\hline & benthic species & 93.99 & 73.34 & 1.28 \\
\hline \multirow[t]{7}{*}{ Trappe Creek/Newport Bay } & depth & 0.13 & 0.12 & 1.09 \\
\hline & bottom temperature & 7.81 & 5.18 & 1.51 \\
\hline & bottom salinity & 4.10 & 25.16 & 0.16 \\
\hline & surface chlorophyll $a$ & 58.03 & 59.18 & 0.01 \\
\hline & bottom oxygen & 1.84 & 6.13 & 0.30 \\
\hline & sediment silt-clay & 1852.41 & 1284.38 & 1.44 \\
\hline & benthic species & 35.66 & 34.72 & 1.03 \\
\hline \multirow[t]{7}{*}{ Chincoteague Bay (MD) } & depth & 0.10 & 0.18 & 0.57 \\
\hline & bottom temperature & 8.63 & 10.47 & 0.82 \\
\hline & bottom salinity & 3.60 & 4.75 & 0.76 \\
\hline & surface chlorophyll $a$ & 21.20 & 33.16 & 0.64 \\
\hline & bottom oxygen & 1.26 & 1.52 & 0.83 \\
\hline & sediment silt-clay & 817.61 & 948.98 & 0.86 \\
\hline & benthic species & 71.96 & 74.67 & 0.96 \\
\hline \multirow[t]{8}{*}{ South River } & depth & 2.74 & 2.73 & 1.00 \\
\hline & bottom temperature & 1.17 & 2.90 & 0.40 \\
\hline & bottom salinity & 0.65 & 0.64 & 1.02 \\
\hline & surface chlorophyll $a$ & 278.20 & 256.73 & 1.08 \\
\hline & bottom oxygen & 5.65 & 4.78 & 1.18 \\
\hline & sediment silt-clay & 1339.92 & 2166.51 & 0.62 \\
\hline & sediment $\mathrm{pb}$ & 547.07 & 485.43 & 1.13 \\
\hline & benthic species & 23.70 & 24.34 & 0.97 \\
\hline \multirow[t]{8}{*}{ Severn River } & depth & 10.27 & 11.68 & 0.88 \\
\hline & bottom temperature & 2.03 & 1.87 & 1.09 \\
\hline & bottom salinity & 2.26 & 2.68 & 0.84 \\
\hline & surface chlorophyll $a$ & 41.39 & 37.99 & 1.09 \\
\hline & bottom oxygen & 11.82 & 11.08 & 1.07 \\
\hline & sediment silt-clay & 2638.48 & 2570.15 & 1.03 \\
\hline & sediment pb & 1286.10 & 1614.96 & 0.80 \\
\hline & benthic species & 72.28 & 77.89 & 0.93 \\
\hline \multirow[t]{3}{*}{ Combined system } & depth & 0.10 & 0.16 & 0.65 \\
\hline & bottom temperature & 5.87 & 7.89 & 0.74 \\
\hline & bottom salinity & 3.06 & 4.61 & 0.66 \\
\hline
\end{tabular}


Table 9. contd....

\begin{tabular}{|l|l|c|c|c|}
\hline \multicolumn{1}{|c|}{ System } & \multicolumn{1}{|c|}{ Variable } & Kriging MSE & Linear interpolation MSE & Kriging MSE / linear MSE \\
\hline \hline \multirow{3}{*}{} & surface chlorophyll $a$ & 58.44 & 98.29 & 0.59 \\
\cline { 2 - 5 } & bottom oxygen & 0.91 & 1.16 & 0.78 \\
\cline { 2 - 5 } & sediment silt-clay & 896.44 & 1129.83 & 0.79 \\
\cline { 2 - 5 } & benthic species & 60.06 & 65.38 & 0.92 \\
\hline
\end{tabular}

The other systems exhibited limited spatial correlation. The differences in MSE indicate little difference between the interpolation methods for these systems.

\section{DISCUSSION}

Strobel et al. [8] used data for the intensively sampled mid-Atlantic small estuarine systems in Table $\mathbf{1}$ that were visited in 1997. Their intent was to provide information on spatial variability within these small systems for use in designing future monitoring programs to describe conditions in individual systems as well as across broad geographic areas. Their results suggest that five sites per system represented a reasonable compromise between the need to characterize an individual system and to keep costs and logistics within expected constraints. Five sites per system were at the low end of the number of sites used in the analyses in this study. However, the results of this study are not inconsistent with those of Strobel et al. [8]: basic characterization methods (except for contouring) provide estimates of condition with acceptable uncertainty using a small number of samples. The use of a systematic grid in the selection of sampling sites contributed to the ability to characterize the systems with a small number of sites.

The spatial model used in the kriging analysis consisted of three components: a spatial component for the trend, accounted for with a nonparametric regression model; a random but spatially correlated component, determined by kriging with the modeled variogram; and a random noise representing residual error. The accounting for the trend component was important if the stationarity assumption for kriging was to be met. For moderate and strong spatial correlation generally less than $50 \%$ of the variance was accounted for by the trend component, indicating importance of the kriged component. For weak spatial correlation, the trend component accounted for up to over $90 \%$ of the variance. Kriging does not provide for improved interpolation when the spatial correlation is weak; an obvious conclusion but worth restating. Mean square errors computed by cross-validation also indicated that kriging was not advantageous over bivariate interpolation for systems with weak spatial correlation of residuals (trend component removed).

The results for the combined system (63 discrete sites) indicated that more discrete sample sites provided for improved kriging results. This was because of the increased number of lags for each separation distance used to compute the empirical variogram and the increase in maximum separation distances used in the empirical variogram. Therefore, if at all possible, neighboring, connected systems should be combined to improve the kriging estimate. The number of sites used for kriging in this analysis (23 to 63) was comparable to that used in other studies where kriging was conducted for estuarine parameters: 38 to 44 in Chang et al. [16]; 31 in Little et al. [14]; and 39 in Poon et al. [34]. However, these numbers used for kriging in estuaries are at the low end of sites typically used in soil studies: 70 to 100 in Chien et al. [33]; and a minimum of 100 in Goovaerts [15, 28]. Webster and Oliver [30] actually recommended a minimum of 150 sites for kriging soil parameters. This number of discrete sites is unreasonable for kriging in estuaries strictly from a cost-effectiveness perspective.

There exist circumstances when other, usually more abundantly sampled, data can be used to assist in predictions. Such data are referred to as secondary data (as opposed to primary data) and are assumed correlated with the primary data. For this situation, cokriging can be attempted (Goovaerts 1999). This requires one to model not only the variograms of the secondary and primary data, but also the cross-variogram between the primary and secondary data.

The spatial variability of variables may be affected by both intrinsic (internal processes affecting the variables, like local biological processes) and extrinsic factors (external processes affecting the variables, like climate). Strong spatial dependence of variables can usually be attributed to intrinsic factors, and weak spatial dependence can be attributed to extrinsic factors. The occurrence of strong spatial dependence in South and Severn Rivers for bottom temperature would generally be thought to be prescribed by extrinsic factors; however, other processes may be important in these systems at the intrinsic level for bottom temperature. The remaining variables exhibit moderate spatial dependence in at most one system, except for depth (three systems).

\section{CONCLUSIONS}

Characterization methods were applied to intensivelysampled small estuarine systems in the mid-Atlantic region of the U.S. Mean values of parameters provided estimates for relative rankings of systems. The results of the characterizations were presented in the context of information that environmental managers could use in their decision-making. Cluster analysis on mean values grouped systems with similar values. T-tests provided estimates of differences in mean values. Standard deviations provided estimates of uncertainty about the mean values. Coefficients of variation gave estimates of overall relative variability. Correlations among variables estimated how variables are related. Empirical cumulative distribution functions (CDFs) illustrated the total 
distribution of the variables irrespective of the underlying statistical distribution. Thresholds of effect were combined with CDFs to estimate fraction of system area in undesirable condition. These characterization methods were valid for all the systems, irrespective of the number of discrete samples (minimum of 6 in systems studied).

Contouring of interpolated values presented the spatial distribution of parameters within a system. Common interpolation methods did not provide direct uncertainty estimates for the interpolated values. Kriging is the best linear unbiased estimator for interpolation and provided direct estimates of uncertainty. The interpolation methods were only applied to systems with at least 23 spatially discrete samples.

Kriging for small estuarine systems with 25-36 spatially discrete sample sites provided a reduction in overall error compared with bivariate interpolation of sample site data. If an adequate number of discrete spatial samples are not available, ordinary kriging should not be expected to be an effective alternative for spatial characterization. An alternative option, which has not been explored in this study but has been addressed in the literature, is cokriging, where one kriges using secondary information for another variable to compute a cross-variogram. Since depth is readily available or is a low cost variable to obtain, cokriging with depth is an obvious option to explore. Kriging is not recommended for shallow, well-mixed small estuarine systems where little or no spatial correlation exists in the residuals after removal of trends component.

\section{ACKNOWLEDGEMENTS}

Thanks to Philip Towbridge, James Heltshe, Anne Kuhn and 2 anonymous reviewers for their critical reviews of this paper. The research described in this paper has been funded, wholly or in part, by the U.S. Environmental Protection Agency. This paper has not been subjected to Agency review. Therefore, it does not necessarily reflect the views of the Agency. Mention of trade names or commercial products does not constitute endorsement or recommendation for use. This is contribution no. AED-09-019 of the Atlantic Ecology Division, National Health and Environmental Effects Research Laboratory.

\section{REFERENCES}

[1] Holland AF, Ed. Near Coastal Plan for 1990: Estuaries. Narragansett, Rhode Island: EPA 600/4-90/033, Office of Research and Development, U.S. Environmental Protection Agency 1990.

[2] Paul JF, Scott KJ, Holland AF, Weisberg SB, Summers JK, Robertson A. The estuarine component of the US E.P.A.'s Environmental Monitoring and Assessment Program. Chem Ecol 1992; 7: 93-116.

[3] Strobel CJ, Buffum HW, Benyi SJ, Paul JF. Environmental monitoring and assessment program: Current status of Virginian Province (US) estuaries. Environ Monit Assess 1999; 56(1): 1-25.

[4] Strobel CJ, Buffum HW, Benyi SJ, Petrocelli EA, Reifsteck DR, Keith DJ. Statistical Summary: EMAP-Estuaries Virginian Province - 1990-1993. Washington, DC 20460: U.S. Environmental Protection Agency, Office of Research and Development1995. Report No.: EPA/620/R-94/026. 1995.

[5] Paul JF, Gentile JH, Scott KJ, Schimmel SC, Campbell DE, Latimer RW. EMAP-Virginian Province Four-Year Assessment (1990-93). Washington, DC: Office of Research and Development, U.S. Environmental Protection Agency1999. Report No.: EPA/620/R-99/004.
[6] Challou JC, Weisberg SB, Kutz FW et al. Assessment of the Ecological Condition of the Delaware and Maryland Coastal Bays: U.S. Environmental Protection Agency, Office of Research and Development, Washington, DC. Report No.: EPA/620/R-96/004. 1996.

[7] Kiddon JA, Paul JF, Buffum HW, et al. Ecological condition of US Mid-Atlantic estuaries, 1997-1998. Mar Pollut Bull 2003; 46(10):1224-44.

[8] Strobel CJ, Paul JF, Hughes MM, Buffum HW, Brown BS, Summers JK. Using information on spatial variability of small estuaries in designing large-scale estuarine monitoring programs. Environ Monit Assess 2000; 63(1):223-36.

[9] Isaaks EH, Srivastava RM. Applied geostatistics. New York: Oxford University Press 1989.

[10] Matheron G. Principles of geostatistics. Econ Geol 1963; 58: 124666.

[11] Eynon B, Switzer P. The variability of rainfall activity. Can J Stat 1983; 11: 11-24.

[12] Aboufirassi M, Marino M. Kriging of water levels in the Souss Aquifer, Morocco. Math Geol 1983; 15: 537-51.

[13] Robertson G. Geostatistics in ecology: interpolating with known variance. Math Geol 1987; 14(87-106).

[14] Little LS, Edwards D, Porter DR. Kriging in estuaries: as the crow flies, or as the fish swims? J Exp Mar Biol Ecol 1997; 213: 1-11.

[15] Goovaerts P. Geostastitical tools for characterizing the spatial variability of microbiological and physico-chemical soil properties. Biol Fertil Soils 1998; 27: 315-34.

[16] Chang YH, Scrimshaw MD, Emmerson RHC, Lesster JN Geostatistical analysis of sampling uncertainty at the Tollesbury Managed Retreat site in Blackwater Estuary, Essex, UK: Kriging and cokriging approach to minimise sampling density. Sci Total Environ 1998; 221: 43-57.

[17] Rathbun SL. Spatial modelling in irregularly shaped regions: kriging estuaries. Environmetrics 1998; 9: 109-29.

[18] USEPA. Condition of the Mid-Atlantic Estuaries: U.S. Environmental Protection Agency, Office of research and Development, Washington, DC1998. Report No.: EPA 600-R-98147.

[19] Everitt B. An R and S-Plus Companion to Multivariate Analysis. London: Springer-Verlag 2007.

[20] Morrison DF. Multivariate Statistical Methods, 2nd ed. New York: McGraw-Hill Book Co.; 1976.

[21] Hyland JL, Herrlinger TJ, Snoots TR, et al. Environmental Quality of Estuaries of the Carolinian Province: 1994. Annual Statistical Summary for the 1994 EMAP-Estuaries Demonstration Project in the Carolinian Province. Silver Spring, Maryland: NOAA/NOS, Office of Ocean Resources Conservation and Assessment1996. Report No.: NOAA Technical Momorandum NOS ORCA 97.

[22] Millard SP, Neerchal NK. Environmental statistics with S-Plus. Boca Raton: CRC Press 2001.

[23] Akima H. A method of bivariate interpolation and smooth surface fitting for irregularly distributed data points. ACM Trans Math Software 1978; 4: 148-64.

[24] SAS Institute. SAS/STAT User's Guide, Version 6, Fourth ed. Cary, North Carolina: SAS Institute, Inc.1989.

[25] Insightful Corp. S-Plus 6 for Windows, Guide to Statistics, Volume 2. Seattle, Washington: "Insightful Corp." 2001.

[26] Cressie N, Hawkins DM. Fitting variogram models by weighted least squares. Math Geol 1980; 12: 563-86.

[27] Cleveland WS, Grosse E, Shyu WM. Local regression models. In: Chambers JM, T.J.Hastie, editors. Statistical Models in S. Pacific Grove, California: Wadsworth and Brooks 1992; pp. 309-76.

[28] Goovaerts P. Geostatistics in soil science: state-of-the-art and perspectives. Geoderma 1999; 89: 1-45.

[29] Wackernagel H. Multivaiirate Geostatistics: An introduction with applications. Berlin: Springer Verlag 1995.

[30] Webster R, Oliver MA. Sample adequately to estimate variograms of soil properties. J Soil Sci 1992; 43: 177-92.

[31] Kaluzny SP, Vega SC, Cardoso TP, Shelly AA. S+SpatialStats, User's Manual for WIndows and UNIX. Seattle, Washington: MathSoft 1998.

[32] Manly BFJ. Randomization, Bootstrap and Monte Carlo Methods in Biology. Second ed. New York: Chapman and Hall 1997.

[33] Chien YJ, Lee DY, Guo HY, Houng KH. Geostatistical analysis of soil properties of mid-west Taiwan soils. Soil Sci 1997; 162(4): 291-8. 
[34] Poon K-F, Wong RW-H, Lam MH-W, Yeung H-Y, Chio TK-T. Geostatistical modelling of the spatial distribution of sewage

pollution in coastal sediments. Water Res 2000; 34(1): 99-108.

Received: October 05, 2009

(C) Paul et al.; Licensee Bentham Open.

This is an open access article licensed under the terms of the Creative Commons Attribution Non-Commercial License (http://creativecommons.org/licenses/by-nc/3.0/) which permits unrestricted, non-commercial use, distribution and reproduction in any medium, provided the work is properly cited. 